Marcin Spyra

\title{
Ocena zgodności z Konstytucją przepisów ustawy o obrocie instrumentami finansowymi ${ }^{1}$
}

\author{
Assessment of conformity to the Constitution of the provisions \\ of the Financial Instruments Trading Act
}

\begin{abstract}
In the assessment of the legitimacy of the constitutional complaint, it was stated that the questioned provision of the Financial Instruments Trading Act to the extent that it allows to consider as a prohibited act placing an order or concluding transactions in accordance with the special regulations established for stock exchange trading by a company operating on a regulated market that affect the volume of trading in company shares and may affect the company's position in indices published by the company, but do not mislead or may not mislead other investors as to the price of shares, is consistent with the Constitution.
\end{abstract}

Keywords: financial market, Constitutional Tribunal

W ocenie zasadności skargi konstytucyjnej stwierdzono, że przepis ustawy o obrocie instrumentami finansowymi w zakresie, w jakim pozwala uznać za czyn zabroniony pod groźbą kary składanie zleceń lub zawieranie transakcji zgodnych ze szczególnymi regulacjami ustalonymi dla obrotu giełdowego przez spółkę prowadzącą działalność na rynku regulowanym, które to zlecenia lub transakcje wpływają na wielkość obrotu akcjami spółki i mogą wpływać na pozycję spółki w publikowanych przez spółkę indeksach, lecz nie wprowadzają lub nie mogą wprowadzać innych inwestorów w błąd co do ceny akcji, jest zgodny z Konstytucją.

Słowa kluczowe: rynek finansowy, Trybunał Konstytucyjny

doktor hab. nauk prawnych, radca prawny, adiunkt Uniwersytet Jagielloński, Wydział Prawa i Administracji, Katedra Prawa Gospodarczego Prywatnego, KRAKÓW, POLSKA • marcin.spyra@uj.edu.pl • https://orcid.org/0000-0002-5357-5225

Na podstawie art. 69 ust. 2 w związku z art. 42 pkt 3 ustawy z dnia 30 listopada 2016 r. o organizacji i trybie postępowania przed Trybunałem Konstytucyjnym (Dz. U. poz. 2072, ze zm.), w imieniu Sejmu Rzeczypospolitej Polskiej przedkładam wyjaśnienia w sprawie skarg konstytucyjnych Grażyny K. z 18 lutego 2019 r. (sygn. akt SK 34/19) i Romana K. z 18 lutego 2019 r. (sygn. akt SK 35/19), rozpoznawanych łącznie pod sygn. akt SK 34/19, jednocześnie wnosząc o stwierdzenie, że art. 183 ust. 1 ustawy z dnia 29 lipca 2005 r. o obrocie instrumenta-

$1 \quad$ Sprawa dot. skarg konstytucyjnych Grażyny K. $z 18$ lutego 2019 r. (sygn. akt SK 34/19) i Romana K. z 18 lutego 2019 r. (sygn. akt SK 35/19), dotyczacych ustawy o obrocie instrumentami finansowymi i rozpoznawanych łacznie pod sygn. akt SK 34/19, projekt stanowiska Sejmu z 18 listopada 2019 r.; BAS-WAKU-1573/19. 
mi finansowymi (t.j. Dz. U. 2018, poz. 2286, ze zm.) w pierwotnym brzmieniu obowiązującym przed 6 maja 2017 r. w związku z art. 39 ust. 2 pkt 1 tej ustawy, uchylonym ustawą z dnia 10 lutego 2017 r. o zmianie ustawy o obrocie instrumentami finansowymi oraz niektórych innych ustaw (Dz. U. poz. 724), w zakresie, w jakim pozwala uznać za czyn zabroniony pod groźbą kary składanie zleceń lub zawieranie transakcji zgodnych ze szczególnymi regulacjami ustalonymi dla obrotu giełdowego przez spółkę prowadzącą rynek regulowany dokonywanych między akcjonariuszami notowanej na giełdzie spółki, które to zlecenia lub transakcje wpływają na wielkość obrotu akcjami spółki i mogą wpływać na pozycję spółki w publikowanych przez spółkę prowadzącą rynek regulowany indeksach, lecz nie wprowadzają lub nie mogą wprowadzać innych inwestorów w błąd co do ceny akcji, jest zgodny $z$ art. 42 ust. 1 w związku $z$ art. 2 Konstytucji, $\mathrm{z}$ art. 64 ust. $1 \mathrm{w}$ związku $\mathrm{z}$ art. 2 Konstytucji oraz z art. 47 Konstytucji.

\section{Uzasadnienie}

\section{Przedmiot kontroli}

1. Przedmiotem kontroli zainicjowanej skargami konstytucyjnymi Grażyny K. (dalej: skarżąca nr 1) oraz Romana K. (dalej: skarżący nr 2), którym Trybunał Konstytucyjny nadał bieg postanowieniami z dnia 15 maja 2019 r. (sygn. akt Ts 28/19 i Ts 29/19), jest art. 183 ust. 1 ustawy z dnia 29 lipca 2005 r. o obrocie instrumentami finansowymi (t.j. Dz. U. 2018, poz. 2286, ze zm.; dalej: u.o.i.f.) w pierwotnym brzmieniu obowiązującym przed 6 maja 2017 r. w związku z art. 39 ust. 2 pkt 1 u.o.i.f., uchylonym ustawą z dnia 10 lutego 2017 r. o zmianie ustawy o obrocie instrumentami finansowymi oraz niektórych innych ustaw (Dz. U. poz. 724; dalej: nowelizacja z 2017 r.), w zakresie, w jakim zaskarżony przepis pozwala uznać za czyn zabroniony pod groźbą kary składanie zleceń lub zawieranie transakcji zgodnych ze szczególnymi regulacjami ustalonymi dla obrotu giełdowego przez spółkę prowadzącą rynek regulowany dokonywanych między akcjonariuszami notowanej na giełdzie spółki, które to zlecenia lub transakcje wpływają na wielkość obrotu akcjami spółki i mogą wpływać na pozycję spółki w publikowanych przez spółkę prowadzącą rynek regulowany indeksach, lecz nie wprowadzają lub nie mogą wprowadzać innych inwestorów w błąd co do ceny akcji.

Zaskarżone przepisy mają następujące brzmienie. Artykuł 183 ust. 1 u.o.i.f. stanowił: „Kto dokonuje manipulacji, o której mowa w art. 39 ust. 2 pkt 1-3, pkt 4 lit. a lub pkt 5-7, podlega grzywnie do 5.000.000 zł albo karze pozbawienia wolności od 3 miesięcy do lat 5, albo obu tym karom łącznie". W art. 39 ust. 2 pkt 1 u.o.i.f. napisano: „2. Manipulację stanowi: 1) składanie zleceń lub zawieranie transakcji wprowadzających lub mogących wprowadzić w błąd co do rzeczywistego popytu, podaży lub ceny instrumentu finansowego, chyba że powody tych działań były 
uprawnione, a złożone zlecenia lub zawarte transakcje nie naruszyły przyjętych praktyk rynkowych na danym rynku regulowanym".

2. Skarżący kwestionują zgodność art. 183 ust. $1 \mathrm{w}$ związku z art. 39 ust. 2 pkt 1 u.o.i.f. $\mathrm{w}$ zakresie wskazanym $\mathrm{w}$ skargach $\mathrm{z}$ art. 42 ust. $1 \mathrm{w}$ związku $\mathrm{z}$ art. 2, art. 21 ust. 1 oraz art. 47 Konstytucji.

\section{Stan faktyczny}

1. Skarżący w 2013 r. byli zaangażowani inwestycyjnie w spółce Boryszew SA. Od 19 kwietnia 2013 r. do 30 kwietnia 2013 r. na 6 spośród 8 sesji w tym okresie dokonali 24 transakcji typu „cross”, których przedmiotem były akcje spółki Boryszew SA. Zgodnie z $\$ 36$ ust. 1 Szczegółowych zasad obrotu giełdowego w systemie UTP, obowiązujących na podstawie uchwały nr 1038/2012 Zarządu Giełdy z dnia 17 października 2012 r. (ze zm.), zlecenia typu „cross” to zlecenia maklerskie z limitem ceny, które mogą być realizowane na sesji giełdowej w transakcjach zawieranych na podstawie dwóch przeciwstawnych zleceń z tym samym limitem ceny (zlecenia kupna i zlecenia sprzedaży tej samej liczby instrumentów finansowych po tej samej cenie), złożonych w tym celu jednocześnie przez tego samego członka giełdy: a) w imieniu i na rachunek dwóch klientów tego członka giełdy albo b) w imieniu i na rachunek tego członka giełdy oraz jego klienta. W inkryminowanych transakcjach skarżący występowali na przemian jako sprzedawca i kupujący. W wyniku tych transakcji ostatecznie stan posiadania skarżących nie zmienił się. Nie odnieśli oni bezpośrednich korzyści ekonomicznych. Gospodarcze znaczenie tych transakcji mogło polegać na zwiększeniu wartości obrotów akcjami Boryszew SA na Giełdzie Papierów Wartościowych w Warszawie, co pozwoliłoby na utrzymanie spółki w głównym indeksie giełdowym (WIG20). Utrzymanie spółki w tym indeksie wiąże się z szeregiem bezspornych, chociaż bezpośrednio niewymiernych korzyści ekonomicznych dla spółki i jej akcjonariuszy. Skarżący wskazywali także na możliwość uzyskania korzyści podatkowych wynikających z realizacji transakcji „cross” zawartych przez nich między 19 a 30 kwietnia $2013 \mathrm{r}$.

Zgodnie z $\$ 36$ ust. 2 Szczegółowych zasad obrotu giełdowego w systemie UTP zlecenia „cross” nie są przyjmowane do arkusza zleceń i nie biorą udziału w określaniu kursu otwarcia, kursu zamknięcia lub kursu określanego w trakcie równoważenia ani też nie podlegają realizacji ze zleceniami maklerskimi oczekującymi na realizację w arkuszu zleceń. Cena zleceń „cross” musi mieścić się w granicach wyznaczonych przez $\$ 36$ ust. 4-5 Szczegółowych zasad obrotu giełdowego w systemie UTP. Punktem odniesienia dla tych granic są - co do zasady ceny zleceń wprowadzonych do arkusza zleceń. Zlecenia "cross” nie wpływają na ceny w systemie notowań ciągłych. Informacja o transakcjach „cross” może wpływać na obraz rynku, wyobrażenia o aktualnym poziomie popytu i podaży na notowane instrumenty finansowe, a w związku z tym na formułowanie prognoz dotyczących kształtowania się ceny instrumentów finansowych w przyszło- 
ści. Transakcje skarżących miały istotny udział w obrotach. Na sześciu sesjach, na których skarżący dokonali inkryminowanych transakcji, wolumen obrotów akcjami spółki Boryszew wielokrotnie przekroczył średnią wolumenu dla tych papierów wartościowych. W ten sposób akcje Boryszew SA wyprzedziły przedostatnią spółkę w rankingu spółek uwzględnianych w indeksie WIG20, a ryzyko utraty korzyści wynikających z przynależności do WIG20 zostało zmniejszone. Odpowiednio zwiększyło się ono dla spółki GTC, która w wyniku działań skarżących znalazła się na ostatnim miejscu w rankingu. Ostatecznie spółka Boryszew nie utrzymała się jednak w indeksie WIG20.

2. Komisja Nadzoru Finansowego zakwalifikowała działania skarżących jako manipulację polegającą na składaniu zleceń i zawieraniu transakcji wprowadzających w błąd co do rzeczywistego popytu, podaży lub ceny instrumentu finansowego. Akt oskarżenia przeciwko skarżącym wniosła do Sądu Rejonowego w Toruniu Prokuratura Okręgowa w Toruniu. Sąd Rejonowy w Toruniu wyrokiem z dnia 21 listopada 2017 r. (sygn. akt II K 1024/15) orzekł, że skarżący dopuścili się czynu zabronionego polegającego na tym, że działając wspólnie i w porozumieniu, w wykonaniu z góry powziętego zamiaru manipulacji akcjami polecili składanie zleceń pełnomocnikowi oraz składali zlecenia i zawierali transakcje mogące wprowadzić w błąd co do rzeczywistego popytu i podaży oraz zawierali transakcje z zamiarem wywołania skutków prawnych innych niż te, dla których faktycznie jest dokonywana czynność prawna, tj. czynu stanowiącego występek z art. 183 ust. 1 u.o.i.f. Sąd Rejonowy przyjął, że celem działania skarżących nie była optymalizacja podatkowa, ale dążenie do „sztucznego” utrzymania spółki Boryszew w gronie spółek należących do indeksu WIG20. O manipulacyjnym charakterze działań skarżących miała także świadczyć metodologia kwestionowanych transakcji, polegająca na częstym powtarzaniu następujących po sobie transakcji kupna i sprzedaży po bieżącej cenie rynkowej. Sąd przyjął, że celem takich działań było wygenerowanie nieproporcjonalnie dużego obrotu oraz całkowite zdominowanie obrotu akcjami spółki Boryszew. Zdaniem Sądu Rejonowego działania skarżących nie doprowadziły wprawdzie do sztucznego ukształtowania ceny rynkowej, miały jednak wpływ na powstanie mylnego wyobrażenia o rzeczywistym popycie i podaży na akcje spółki Boryszew oraz na ich płynność. Okoliczność taka wystarczyła do zakwalifikowania działania skarżących jako przestępstwa $\mathrm{z}$ art. 183 ust. 1 u.o.i.f. Sąd odnosił się przy tym do brzmienia tego przepisu nadanego nowelizacją z 2017 r. Skarżący złożyli od tego wyroku apelację do Sądu Okręgowego w Toruniu. Sąd odwoławczy podzielił zasadniczo ustalenia faktyczne oraz rozważania prawne sądu pierwszej instancji. W punkcie pierwszym zaskarżonego wyroku sprecyzował jedynie podstawę prawną kwalifikacji czynu popełnionego przez skarżących oraz wyeliminował określenie „także z zamiarem wywołania innych skutków prawnych niż te, dla osiągnięcia których faktycznie jest dokonywana dana czynność prawna”. W uzasadnieniu Sąd Okręgowy sprecyzował także, że zgodnie z art. $4 \$ 1$ ustawy z dnia 6 czerwca 1997 r. - 
Kodeks karny (t.j. Dz. U. 2018, poz. 1600, ze zm.; dalej: k.k.) zastosował wobec czynu skarżących art. 183 ust. 1 u.o.i.f. w brzmieniu obowiązującym w dniu orzekania, ponieważ przewiduje ono węższy zakres pojęcia manipulacji. Zdaniem sądu drugiej instancji do znamion czynu zabronionego określonego w art. 183 ust. 1 u.o.i.f. nie należą ani działanie w celu uzyskania korzyści majątkowych, ani koniunktywne spełnienie znamion wprowadzenia w błąd co do popytu i podaży oraz ceny instrumentów finansowych. Wyrok Sądu Okręgowego w sprawie skarżących jest prawomocny i nie przysługują od niego żadne zwykłe środki odwoławcze.

\section{Analiza formalnoprawna}

1. Dopuszczalność rozpoznania skargi konstytucyjnej zależy od spełnienia przesłanek wynikających z art. 79 ust. 1 Konstytucji oraz art. 53 ustawy z dnia 30 listopada 2016 r. o organizacji i trybie postępowania przed Trybunałem Konstytucyjnym (Dz. U. poz. 2072, ze zm.; dalej: ustawa o TK). Zdaniem Sejmu skarga konstytucyjna rozpoznawana pod sygnaturą akt SK 34/19 realizuje te przesłanki. Przyjęcie tej konkluzji wymaga jednak rozstrzygnięcia kilku wątpliwości.

2. Pierwszym zagadnieniem formalnym, do którego należy się odnieść, ustosunkowując się do rozpoznawanych skarg, jest kwestia określenia przedmiotu kontroli. Skarżący wnieśli o stwierdzenie niezgodności z powołanymi wzorcami konstytucyjnymi art. 183 ust. 1 u.o.i.f. w związku $z$ art. 39 ust. 2 pkt 1 u.o.i.f. Zdecydowana większość zarzutów oraz ich uzasadnienia odnoszą się jednak do definicji manipulacji transakcyjnej wynikającej $\mathrm{z}$ art. 39 ust. 2 pkt 1 u.o.i.f. Może to nasuwać wątpliwość dotyczącą rzeczywistego przedmiotu zaskarżenia w sprawie, w szczególności należy rozważyć, czy art. 39 ust. 2 pkt 1 u.o.i.f. nie jest właściwym, samodzielnym przedmiotem zaskarżenia w sprawie. Uważna lektura zarzutów skarżących prowadzi do wniosku, że całość zarzutów skarżących została sformułowana w kontekście ich odpowiedzialności karnoprawnej. Artykuł 39 ust. 2 pkt 1 u.o.i.f. nie jest w związku z tym analizowany jako odrębna, abstrakcyjna regulacja. Zarzuty nie dotyczą także każdego aspektu zastosowania tego przepisu w zakresie, $\mathrm{w}$ jakim pozwala on zakwalifikować jako manipulację transakcje wpływające na wielkość popytu i podaży, ale niewpływające na cenę instrumentów finansowych. Dokonana przez skarżących analiza nie odnosi się w szczególności do prywatnoprawnych oraz administracyjnoprawnych aspektów manipulacji. Treść art. 39 ust. 2 pkt 1 u.o.i.f. jest oceniana przez skarżących wyłącznie jako element opisu znamion czynu zabronionego. Jest także oceniana przez pryzmat wzorca kontroli odnoszącego się do regulacji prawnokarnej (art. 42 ust. 1 Konstytucji). Pozostałe wzorce kontroli mają służyć wyłącznie albo subsydiarnie jako kryterium oceny prawidłowości sposobu skonstruowania opisu czynu zabronionego (art. 2 Konstytucji), albo jako kryterium wyznaczenia dopuszczalnego zakresu ingerencji normy karnej w konstytucyjne prawa skarżących (art. 21 ust. 1 Konstytucji). $Z$ tego względu Sejm uznaje, że 
wskazanie przez skarżących art. 183 ust. 1 u.o.i.f. w jego pierwotnym brzmieniu jako przedmiotu kontroli w związku z art. 39 ust. 2 pkt 1 u.o.i.f. w jego pierwotnym brzmieniu jest prawidłowe. Jak zostanie to wykazane w dalszej części pisma (pkt III.5), należy uznać, że obowiązywanie art. 183 ust. 1 u.o.i.f. w związku $\mathrm{z}$ art. 39 ust. 2 pkt 1 u.o.i.f. w ich pierwotnym brzmieniu było niezbędną przesłanką wydania wyroków skazujących w sprawach skarżących, czym spełniona została wynikająca z art. 79 ust. 1 Konstytucji przesłanka związku funkcjonalnego zaskarżonych przepisów z zarzucanym naruszeniem konstytucyjnych praw i wolności.

3. Kolejnym istotnym zagadnieniem jest poprawność sformułowania przez skarżących wzorców kontroli. Skarżący wnoszą o stwierdzenie sprzeczności zaskarżonego przepisu z art. 42 ust. 1 w związku z art. 2, art. 21 ust. 1 oraz art. 47 Konstytucji. Zdaniem Sejmu wskazane przez skarżących konstytucyjne wzorce kontroli nie odpowiadają w pełni sformułowanemu przez nich problemowi konstytucyjnemu. W europejskiej kulturze prawnej ugruntowana jest zasada falsa demonstratio non nocet, w myśl której decydujące znaczenie ma istota sprawy, a nie jej oznaczenie. Należy je zatem przypisać nie tyle żądaniu wskazanemu w petitum wniosku (skargi konstytucyjnej, pytania prawnego), ile całej jego treści z uwzględnieniem argumentacji zawartej w uzasadnieniu pisma procesowego. Zasada ta znajduje zastosowanie w odniesieniu nie tylko do przedmiotu kontroli, ale także do wzorców kontroli. Trybunał, ustalając wzorce kontroli, ma obowiązek wziąć pod uwagę nie tylko petitum pisma rozpoczynającego postępowanie, ale także „treści normatywne, które podmiot inicjujący postępowanie wiąże z tymi przepisami" (por. np. wyroki TK: z dnia 14 marca 2006 r., sygn. akt SK 4/05; z dnia 7 marca 2007 r., sygn. akt K 25/05; z dnia 13 listopada 2007 r., sygn. akt P 42/06; postanowienia TK: z dnia 6 września 2006 r., sygn. akt SK 35/06; z dnia 3 kwietnia 2007 r., sygn. akt SK 85/06; z dnia 9 maja 2007 r., sygn. akt SK 98/06).

Zdaniem Sejmu skarżący sformułowali w istocie trzy problemy konstytucyjne. Pierwszy dotyczy oceny zachowania w zaskarżonym przepisie właściwych standardów określoności czynu zabronionego oraz wiążącego się z tym problemem zachowania standardów poprawnej legislacji, a także zasady zaufania do państwa i tworzonego przez nie prawa. W tym zakresie właściwym wzorcem kontroli jest art. 42 ust. 1 Konstytucji oraz powołany związkowo art. 2 Konstytucji, z którego jako konsekwencja zasady demokratycznego państwa prawa wywodzone są zasady określoności przepisów oraz zasada zaufania do państwa oraz tworzonego przez nie prawa. Drugi problem konstytucyjny dotyczy dopuszczalności penalizacji zachowań polegających na składaniu zleceń lub zawieraniu transakcji zgodnych ze szczególnymi regulacjami ustalonymi dla obrotu giełdowego przez spółkę prowadzącą rynek regulowany dokonywanych między akcjonariuszami notowanej na giełdzie spółki, które to zlecenia lub transakcje wpływają na wielkość obrotu akcjami spółki i mogą wpływać na pozycję spółki w publikowanych przez spółkę prowadzącą rynek regulowany indeksach, lecz 
nie wprowadzają lub nie mogą wprowadzać innych inwestorów w błąd co do ceny akcji. Artykuł 42 ust. 1 Konstytucji nie jest właściwym wzorcem kontroli w tym zakresie. Z tego przepisu Konstytucji wynikają gwarancje o charakterze formalnym - w pierwszym rzędzie nakaz zachowania właściwego standardu określoności przepisów prawa karnego (por. szczegółowe uzasadnienie w punkcie IV.2 pisma). Z treści art. 42 ust. 1 Konstytucji nie wynika bezpośrednio jakiekolwiek kryterium materialne, którym powinien posługiwać się ustawodawca, rozstrzygając o tym, czy określone zachowanie może być przedmiotem zakazu o charakterze prawnokarnym. Z orzecznictwa TK wynika jednak jednoznacznie, że władza ustawodawcza nie ma swobody w zakresie decydowania o tym, które zachowania jednostki mogą zostać zakazane pod groźbą kary (por. np. wyroki TK: z dnia 9 października 2012 r., sygn. akt P 27/11; z dnia 1 lipca 2014 r., sygn. akt SK 6/12; z dnia 6 października 2015 r., sygn. akt SK 54/13). Stanowisko to jest akceptowane także przez doktrynę prawa konstytucyjnego (por. np. K. Wojtyczek, Zasada proporcjonalności jako granica prawa karania, „Czasopismo Prawa Karnego i Nauk Penalnych” 1999, z. 2, s. 40-46). Właściwym kryterium kontroli w odniesieniu do wyznaczenia granic dopuszczalności interwencji prawa karnego w prawa i wolności jednostki są przepisy Konstytucji określające te prawa i wolności. W odniesieniu do zarzutu nieproporcjonalnej ingerencji prawa karnego w uprawnienia skarżących jako akcjonariuszy spółki publicznej właściwym wzorcem kontroli jest art. 64 ust. 1 Konstytucji, z którego wynika m.in. konstytucyjne prawa własności i innych praw majątkowych, a także pozostający z nim w związku art. 2 Konstytucji, z którego wynika zasada proporcjonalności. Trzecim problemem konstytucyjnym sformułowanym przez skarżących jest kwestia naruszenia ich prawa do czci i dobrego imienia. W tym zakresie samodzielnym wzorcem kontroli jest art. 47 Konstytucji.

W konsekwencji należy przyjąć, że przedmiotem postępowania jest ocena zgodności art. 183 ust. 1 u.o.i.f. w pierwotnym brzmieniu w związku $\mathrm{z}$ art. 39 ust. 2 pkt 1 u.o.i.f., uchylonym nowelizacją z 2017 r., w zakresie, w jakim pozwala uznać za czyn zabroniony pod groźbą kary składanie zleceń lub zawieranie transakcji zgodnych ze szczególnymi regulacjami ustalonymi dla obrotu giełdowego przez spółkę prowadzącą rynek regulowany dokonywanych między akcjonariuszami notowanej na giełdzie spółki, które to zlecenia lub transakcje wpływają na wielkość obrotu akcjami spółki i mogą wpływać na pozycję spółki w publikowanych przez spółkę prowadzącą rynek regulowany indeksach, lecz nie wprowadzają lub nie mogą wprowadzać innych inwestorów w błąd co do ceny akcji, z art. 42 ust. 1 w związku z art. 2 Konstytucji, z art. 64 ust. 1 w związku z art. 2 Konstytucji oraz $\mathrm{z}$ art. 47 Konstytucji.

4. Zgodnie $\mathrm{z}$ art. 79 ust. 1 Konstytucji przedmiotem skargi konstytucyjnej może być ustawa lub inny akt normatywny, na podstawie którego sąd lub organ administracji publicznej orzekły ostatecznie o wolnościach lub prawach skarżącego albo o jego obowiązkach określonych w Konstytucji. Wynikająca stąd zależ- 
ność między przedmiotem skargi konstytucyjnej a jednostkowym orzeczeniem podjętym wobec skarżącego przesądza o jego legitymacji do wystąpienia z tym środkiem ochrony praw i wolności, a jednocześnie nadaje skardze konstytucyjnej niezbędny - w świetle założeń wyrażonych w przywołanym przepisie - charakter środka inicjowania tzw. konkretnej kontroli prawa przed Trybunałem Konstytucyjnym. Zgodnie ze stanowiskiem wyrażonym przez TK w postanowieniu z dnia 19 października 2004 r. (sygn. akt SK 13/03) przedmiotem skargi konstytucyjnej „mogą być wyłącznie unormowania wykazujące złożoną (podwójną) kwalifikację. Będąc podstawą ostatecznego orzeczenia sądu lub organu administracji publicznej, winny one stanowić jednocześnie bezpośrednie źródło naruszenia konstytucyjnych wolności lub praw skarżącego. Innymi słowy, to w normatywnej treści kwestionowanych przepisów upatrywać należy przyczyny niedozwolonej w świetle unormowań konstytucyjnych - ingerencji w sferę gwarantowanych praw podmiotowych skarżącego". Konieczną przesłanką skargi jest więc wykazanie związku między kwestionowanym unormowaniem a ostatecznym orzeczeniem, z którego wydaniem skarżący wiąże zarzut naruszenia swoich praw (zob. przykładowo postanowienia TK: z dnia 19 października 2004 r., sygn. akt SK 13/03; z dnia 15 lipca 2002 r., sygn. akt Ts 5/02; z dnia 17 grudnia 2013 r., sygn. akt SK 59/12; z dnia 1 lipca 2014 r., sygn. akt SK 6/12; z dnia 7 lutego 2018 r., sygn. akt SK 20/15). Ponadto przepisy wskazane przez inicjatora postępowania, będąc podstawą ostatecznego orzeczenia sądu, powinny jednocześnie stanowić bezpośrednie źródło naruszenia jego konstytucyjnych wolności lub praw (dotyczyć go osobiście). Naruszenie musi mieć charakter osobisty i aktualny (rzeczywisty), a nie potencjalny, czyli możliwy do wyobrażenia w realiach innych niż sytuacja faktyczna i prawna skarżącego (zob. np. postanowienia TK: z dnia 17 marca 1998 r., sygn. akt Ts 11/97; z dnia 19 października 2004 r., sygn. akt SK 13/03; z dnia 9 lipca 2012 r., sygn. akt SK 19/10). Zgodnie z wielokrotnie wyrażanym przez TK poglądem w tym trybie skargi konstytucyjnej zaskarżyć można tylko taki przepis, który wpłynął na rozstrzygnięcie sądu lub innego organu, zdeterminował w sensie prawnym treść tego rozstrzygnięcia (zob. postanowienia TK: z dnia 4 lipca 2001 r., sygn. akt Ts 101/00; z dnia 6 lipca 2005 r., sygn. akt SK 25/03; z dnia 14 października 2009 r., sygn. akt Ts 54/08; z dnia 7 lipca 2009 r., sygn. akt Ts 221/07).

Przedmiotem zaskarżenia w trybie art. 79 ust. 1 Konstytucji może być zatem wyłącznie przepis, którego brak w systemie prawa prowadziłby - lub mógłby doprowadzić - do tego, że rozstrzygnięcie sprawy skarżącego byłoby inne (zob. np. postanowienia TK: z dnia 9 listopada 1999 r., sygn. akt Ts 19/99; z dnia 6 lutego 2001 r., sygn. akt Ts 139/00; z dnia 20 czerwca 2001 r., sygn. akt Ts 97/00; z dnia 17 kwietnia 2002 r., sygn. akt Ts 80/01; z dnia 28 kwietnia 2005 r., sygn. akt Ts 187/04; z dnia 10 grudnia 2012 r., sygn. akt Ts 232/11; z dnia 16 października 2013 r., sygn. akt Ts 50/13; z dnia 28 lutego 2018 r., sygn. akt Ts 34/17; wyrok TK z dnia 21 września 2011 r., sygn. akt SK 6/10). Innymi słowy, dopuszczalność skargi konstytucyjnej zależy - co do zasady - od tego, czy w wyniku 
zastosowania aktu normatywnego pogorszyła się sytuacja prawna skarżącego w kontekście jego konstytucyjnych praw i wolności (zob. Z. Czeszejko-Sochacki, Formy naruszenia konstytucyjnych wolności lub praw [w:] Skarga konstytucyjna, red. J. Trzciński, Warszawa 2000, s. 75; L. Jamróz, Skarga konstytucyjna. Wstępne rozpoznanie, Białystok 2011, s. 192). Skarżący powinien to wykazać w ramach spełnienia wymogu „uprawdopodobnienia naruszenia”, które to uprawdopodobnienie uzasadnia udzielenie ochrony w trybie skargi konstytucyjnej. Powyższe przesłanki dopuszczalności wydania wyroku w sprawie zainicjowanej skargą konstytucyjną wynikają z charakteru i celu tego środka prawnego. Jego celem nie jest abstrakcyjna kontrola prawidłowości norm powszechnie obowiązujących w polskim systemie prawa, ale ma on usunąć konkretne skutki, które dla jednostki ma zastosowanie wadliwej konstytucyjnie normy w konkretnej, jednostkowej sprawie skarżącego. Z założenia skarżący nie występuje ze skargą w celu obrony interesu publicznego (zgodności hierarchicznej norm obowiązujących w systemie prawa), lecz robi to ze względu na własny interes prywatny - licząc na to, że sukces przed TK przełoży się następnie na możliwość wyeliminowania z obrotu prawnego orzeczenia (innego rozstrzygnięcia), które skarżący uznaje za oparte na przepisie niezgodnym z Konstytucją (J. Trzciński, M. Wiącek, komentarz do art. 79 [w:] Konstytucja Rzeczypospolitej Polskiej. Komentarz, t. I, red. L. Garlicki, M. Zubik, Warszawa 2016, s. 906-907). W konsekwencji wydanie wyroku w sprawie zainicjowanej skargą konstytucyjną nie jest dopuszczalne w sytuacji, w której stwierdzenie niekonstytucyjności zaskarżonego przepisu nie może mieć wpływu na pozycję prawną skarżącego, ponieważ nawet w razie wydania wyroku stwierdzającego niekonstytucyjność zaskarżonego przepisu ani treść orzeczenia sądu lub rozstrzygnięcia organu administracji publicznej nie uległaby zmianie, ani nie istniałby adekwatny związek przyczynowy między obowiązywaniem niekonstytucyjnego przepisu a szkodą poniesioną przez skarżącego.

5. Skarżący domagają się kontroli konstytucyjnej art. 183 ust. 1 u.o.i.f. w jego pierwotnym brzmieniu obowiązującym przed 6 maja 2017 r. Sądy orzekające $\mathrm{w}$ ich sprawach zgodnie $\mathrm{z}$ art. $4 \$ 1 \mathrm{k} . \mathrm{k}$. jako podstawę rozstrzygnięcia wskazały art. 183 ust. 1 u.o.i.f. w brzmieniu nadanym nowelizacją z 2017 r. Sądy przyjęły zgodnie, że z pierwotnego brzmienia art. 183 ust. 1 u.o.i.f. nie wynika norma względniejsza dla skarżących, stąd zgodnie z art. $4 \$ 1$ k.k. podstawą wyroku uczyniły „ustawę nową” (por. wyrok sądu okręgowego, s. 4). Nie oznacza to jednak, że art. 183 ust. 1 u.o.i.f. w jego pierwotnym brzmieniu nie był podstawą ostatecznego orzeczenia o wolnościach i prawach skarżących w rozumieniu art. 79 ust. 1 Konstytucji. Warunkiem zastosowania „nowej ustawy” zgodnie z art. 4 $\$ 1$ k.k. jest okoliczność, że czyn sprawcy był w ogóle czynem zabronionym pod groźbą kary przez „poprzednią ustawę” w czasie jego popełnienia (por. np.: L. Gardocki, Prawo karne, Warszawa 2009, s. 18; S. Żółtek, komentarz do art. 4 [w:] Kodeks karny. Część ogólna. Art. 1-116, red. M. Królikowski, R. Zawłocki, Warszawa 2017, nb. 6, s. 189; B. Kunicka-Michalska, komentarz do art. 4 [w:] 
Kodeks karny. Komentarz, red. R.A. Stefański, Warszawa 2018, nb. 34, s. 82; J. Lachowski, komentarz do art. 4 [w:] Kodeks karny. Komentarz, red. V. Konarska-Wrzosek, Warszawa 2018, uw. 5, s. 54). Nawet w przypadku, w którym sąd orzeka o popełnieniu przestępstwa oraz karze na podstawie nowej ustawy, w istocie stosuje także „poprzednią ustawę”, dokonując oceny, czy w chwili popełnienia zarzucanego czynu zachowanie sprawcy spełniało znamiona czynu zabronionego pod groźbą kary. Na tej zasadzie w sprawie skarżących sądy niezależnie od zastosowania art. 183 ust. 1 w brzmieniu nadanym nowelizacją z 2017 r. dokonały także kwalifikacji zachowania skarżących, oceniając, że spełniało ono znamiona czynu zabronionego określonego w pierwotnym brzmieniu tego przepisu. Skarżący wnoszą zatem o kontrolę konstytucyjną przepisu, którego zastosowanie było niezbędną przesłanką orzeczenia o ich odpowiedzialności karnej. Gdyby w chwili dokonania zarzucanego im czynu art. 183 ust. 1 u.o.i.f. nie obowiązywał lub gdyby wynikająca z niego norma nie penalizowała zachowania skarżących, sąd musiałby wydać wyrok uniewinniający. Przesądza to o istnieniu związku funkcjonalnego między problemem konstytucyjności zaskarżonego przepisu a treścią orzeczenia w sprawie skarżących.

6. Dopuszczalność wydania orzeczenia w postępowaniu zainicjowanym skargą konstytucyjną zależy także od spełnienia wymogów wskazanych w art. 53 ust. 1 ustawy o TK. Dotyczy to przede wszystkim wymogu uzasadnienia przez skarżących zarzutu niekonstytucyjności. Obowiązek taki wynika de lege lata $\mathrm{z}$ art. 53 ust. 1 pkt 3 ustawy o TK. Treść tego wymogu oraz jego znaczenie proceduralne zostały szczegółowo wyjaśnione w orzecznictwie TK. W tym zakresie aktualność zachowują m.in. poglądy Trybunału zawarte w uzasadnieniach orzeczeń dotyczących: art. 47 ust. 1 pkt 3 ustawy z dnia 1 sierpnia 1997 r. o Trybunale Konstytucyjnym (Dz. U. 1997, Nr 102, poz. 643, ze zm.), art. 65 ust. 1 pkt 3 ustawy z dnia 25 czerwca 2015 r. o Trybunale Konstytucyjnym (Dz. U. 2015, poz. 1064, ze zm.) oraz art. 48 ust. 1 pkt 3 ustawy z dnia 22 lipca 2016 r. o Trybunale Konstytucyjnym (Dz. U. 2016, poz. 1157, ze zm.). Jest to wymóg odrębny od wymogu sformułowania zarzutu. Uzasadnienie skargi nie może polegać na powtórzeniu treści zarzutów. Trybunał podkreślił także, że poprzestanie na lakonicznym lub zdawkowym uzasadnieniu zarzutu nie pozwala na przyjęcie, że zostały spełnione ustawowe wymogi dotyczące treści skargi konstytucyjnej, co powinno skutkować odmową nadania jej dalszego biegu. Zdaniem Trybunału „niedopuszczalne jest samodzielne precyzowanie przez Trybunał, a tym bardziej uzasadnianie, jedynie ogólnikowo sformułowanych zarzutów niekonstytucyjności zaskarżonych przepisów" (por. postanowienia TK: z dnia 4 lutego 2009 r., sygn. akt Ts 256/08; z dnia 4 marca 2015 r., sygn. akt Ts 155/13; wyrok TK z dnia 27 lutego 2018 r., sygn. akt SK 25/15). Prawidłowo sformułowane uzasadnienie winno zawierać argumentację, która przez porównanie treści zakwestionowanej regulacji ustawy z treścią będących wzorcami kontroli norm konstytucyjnych określałaby i uprawdopodabniałaby ich wzajemną niezgodność (zob. postanowienie TK z dnia 14 marca 
2016 r., sygn. akt Ts 355/15). Wymaga to zrekonstruowania wzorca konstytucyjnego, a także szczegółowego opisu zakwestionowanego przepisu. Nie jest wystarczającym uzasadnieniem samo powołanie wcześniejszych orzeczeń TK dotyczących danego wzorca (zob. postanowienie TK z dnia 14 marca 2016 r., sygn. akt Ts 355/15) ani tym bardziej zdawkowe powtórzenie treści sformułowanych zarzutów. Wymogi dotyczące szczegółowego uzasadnienia skargi są proporcjonalnie wyższe w sprawach, w których za siłą domniemania konstytucyjności przemawia fakt, że zaskarżony przepis należy do powszechnie i od dawna uznanych instytucji systemu prawnego (por. postanowienie TK z dnia 15 grudnia 1999 r., sygn. akt Ts 111/99). Zdaniem Sejmu skargi konstytucyjne rozpoznawane wspólnie pod sygn. akt SK 34/19 spełniają tę przesłankę.

7. W związku z powyższym, zdaniem Sejmu, skargi konstytucyjne rozpoznawane łącznie pod sygnaturą akt SK 34/19 mogą zostać rozpoznane w zakresie wskazanym przez skarżących, przy czym właściwymi wzorcami kontroli powinny być art. 42 ust. 1 Konstytucji w związku z art. 2 Konstytucji oraz art. 64 ust. 1 Konstytucji.

\section{Zarzut naruszenia art. 42 ust. 1 w związku z art. 2 Konstytucji}

\section{- 1. Zarzuty skarżących}

Skarżący wskazują, że art. 183 ust. 1 u.o.i.f. w jego pierwotnym brzmieniu ze względu na posłużenie się techniką odesłania do art. 39 ust. 2 pkt 1 u.o.i.f. w brzmieniu uchylonym nowelizacją z 2017 r. nastręcza trudności interpretacyjnych zarówno w części określającej znamiona czynu zagrożonego karą, jak i w części określającej okoliczności wyłączające karalność czynu. Sposób, w jaki ustawa o obrocie instrumentami finansowymi definiowała manipulację, pozwalał, zdaniem skarżących, na zupełnie dowolną interpretację znamion czynu zabronionego przez organy nadzoru nad rynkiem oraz sądy orzekające w sprawach karnych. Skarżący podnoszą, że opis znamion czynu zabronionego odnosi się do wzorców rzeczywistego i innego niż rzeczywisty (pozornego lub fikcyjnego) popytu, podaży lub ceny instrumentu finansowego, które nie zostały w jakikolwiek sposób sprecyzowane w ustawie. Zaskarżony przepis, odwołując się do kategorii wprowadzenia w błąd, nie określał grona osób, które w wyniku składanych zleceń lub zawieranych transakcji miałyby zostać wprowadzone w błąd co do rzeczywistego popytu, podaży lub ceny instrumentu finansowego. Skarżący wskazują także, że zaskarżony przepis nie określa, czy od osób, które mogą zostać wprowadzone w błąd przez inkryminowane transakcje, wymaga się odpowiedniego poziomu wiedzy o rynku instrumentów finansowych, czy też chodzi o wprowadzenie w błąd osób pozbawionych odpowiedniej wiedzy i doświadczenia. Skarżący kwestionują także poprawność posłużenia się pojęciem rzeczywistej ceny instrumentu finansowego. Zdaniem skarżących cena zawsze wynika $\mathrm{z}$ aktualnego popytu i podaży, które wyrażają się w treści zleceń składanych przez inwestorów. 
Każda zatem cena wynikająca ze złożonych zleceń jest ceną rzeczywistą. Skarżący wskazują także, że w opisie pojęcia manipulacji instrumentami finansowymi jedynie pojęcie popytu zostało opatrzone kwalifikatorem „rzeczywisty”. Podaż lub cena instrumentu finansowego nie zostały w jakikolwiek sposób zdefiniowane, co ma prowadzić do zupełnie dowolnych interpretacji. Skarżący podnoszą, że przesłanka wyłączająca bezprawność działania sprawcy została zdefiniowana nieprecyzyjnie. Ma to wynikać stąd, że posłużenie się sformułowaniem „chyba że powody tych działań były uprawnione” odsyła do niesprecyzowanego systemu norm i ma powodować zupełną dowolność w ocenie bezprawności działania osób oskarżanych o manipulację na rynku.

Przytoczone przez skarżących okoliczności mają, ich zdaniem, uzasadniać zarzut naruszenia zasady określoności czynu zabronionego wynikającej z art. 42 ust. 1 Konstytucji. Skarżący dowodzą także, że sposób określenia w zaskarżonym przepisie znamion czynu zabronionego polegający na odesłaniu do treści art. 39 ust. 2 pkt 1 u.o.i.f. nie spełnia właściwych kryteriów konstruowania przepisów karnych wynikających z art. 2 Konstytucji. Skarżący dowodzą, że zaskarżony przepis narusza wynikającą z art. 2 Konstytucji zasadę określoności przepisów, co powoduje dowolność w ustalaniu przez sądy tego, co jest czynem zabronionym przez ustawę pod groźbą kary. Zdaniem skarżących tym samym doszło także do naruszenia zasady zaufania obywateli do państwa i stanowionego przez nie prawa. Źródłem tej zasady jest art. 2 Konstytucji. Skarżący wywodzą, że art. 183 ust. 1 w związku z art. 39 ust. 2 pkt 1 u.o.i.f. w zakresie, w jakim pozwala uznać za czyn zabroniony składanie zleceń lub zawieranie transakcji, które ze względu na szczególny charakter, wynikający z regulacji obowiązujących w obrocie giełdowym, nie wprowadzają lub nie mogą wprowadzać w błąd co do ceny instrumentu finansowego, jest niezgodny z art. 42 ust. $1 \mathrm{w}$ związku z art. 2 Konstytucji przez to, że narusza zasadę zaufania jednostki do państwa i stanowionego przez nie prawa. W odniesieniu do instytucji zaufania publicznego, podlegających szczególnemu nadzorowi organów państwowych i stanowiących w zakresie swej działalności normy wiążące użytkowników tych instytucji, wymaga się, aby ujemnych konsekwencji nieefektywnego nadzoru nad działalnością tych instytucji w zakresie ustanawiania norm wiążących ich użytkowników nie ponosiła jednostka, której działanie mieściło się w ramach reguł ustanowionych przez instytucje zaufania publicznego. Skarżący uważają, że swoje działania opierali na zaufaniu, że ich zachowanie pozostaje $\mathrm{w}$ zgodzie $\mathrm{z}$ zasadami obrotu na giełdzie, a ponieważ nie wywołuje błędu co do ceny instrumentu finansowego, jest działaniem legalnym, które nie może być zakwalifikowane jako zakazana manipulacja na rynku.

\section{Wzorzec kontroli}

Przywołany jako wzorzec kontroli art. 42 ust. 1 Konstytucji wyraża zasadę nullum crimen sine lege, nulla poena sine lege. Zgodnie z tym przepisem „odpowiedzialności karnej podlega ten tylko, kto dopuścił się czynu zabronionego pod 
groźbą kary przez ustawę obowiązującą w czasie jego popełnienia. Zasada ta nie stoi na przeszkodzie ukaraniu za czyn, który w czasie jego popełnienia stanowi przestępstwo w myśl prawa międzynarodowego". Z ogólnej zasady nullum crimen sine lege, nulla poena sine lege wyprowadzone są następujące zasady szczegółowe: - nullum crimen, nulla poena sine lege scripta, zgodnie z którą źródłem określenia przestępstwa i kary kryminalnej mogą być tylko ustawa bądź akty równe ustawie;

- nullum crimen, nulla poena sine lege stricta, zgodnie z którą w prawie karnym zabronione jest stosowanie analogii mającej na celu poszerzenie zakresu kryminalizacji lub penalizacji, jak również dokonywanie wykładni rozszerzającej przepisu prawa karnego na niekorzyść sprawcy;

- nullum crimen, nulla poena sine lege certa, zgodnie z którą określenie przestępstwa i kary powinno charakteryzować się dostateczną precyzyjnością;

- nullum crimen, nulla poena sine lege praevia, zgodnie z którą zabronione jest wsteczne działanie ustawy karnej w takim zakresie, w jakim pogarsza to sytuację sprawcy (zob. R. Dębski, Pozaustawowe znamiona przestępstwa. O ustawowym charakterze norm prawa karnego i znamionach typu czynu zabronionego nie określonych w ustawie, Łódź 1995, s. 19-20; A Wąsek, Kodeks karny. Komentarz, t. I, Gdańsk 1999, s. 16-20; W. Wróbel, Zmiana normatywna i zasady intertemporalne, Warszawa 2003, s. 383-384).

Zasada określoności opisu czynu zabronionego jest szczególnym przejawem ogólnej zasady określoności przepisów powszechnie obowiązujących, wynikającej z art. 2 Konstytucji (por. np. wyrok TK z dnia 22 czerwca 2010 r., sygn. akt SK 25/08). Kwestia określoności norm karnych była podejmowana w dotychczasowym orzecznictwie Trybunału Konstytucyjnego. Jak wskazano w uzasadnieniu postanowienia z dnia 25 września 1991 r. (sygn. akt S 6/91), „w demokratycznym państwie prawa funkcją prawa karnego nie jest tylko ochrona państwa i jego instytucji, nie jest także tylko ochrona społeczeństwa lub poszczególnych jednostek przed przestępstwami, ale także, w nie mniejszym stopniu, ochrona jednostki przed samowolą państwa. Prawo karne stwarza dla władzy w demokratycznym państwie prawa barierę, poza którą obywatel powinien czuć się bezpieczny $\mathrm{w}$ tym sensie, że bez przekroczenia pola zabronionego pod groźbą kary nie może być pociągnięty do odpowiedzialności karnej. Prawo karne ma wyznaczyć wyraźne granice między tym, co jest dozwolone, a tym, co jest zabronione. Bariera, o której tu mowa, nie powinna być usuwana dla żadnych celów politycznych lub innych. Prawo karne nie jest bowiem instrumentem mającym służyć zachowaniu władzy, lecz jest właśnie tej władzy ograniczeniem”. A ponadto „z powyższych założeń wynika, że w demokratycznym państwie prawa prawo karne musi być oparte przynajmniej na dwóch podstawowych zasadach: określoności czynów zabronionych pod groźbą kary (nullum crimen, nulla poena sine lege) oraz na zakazie wstecznego działania ustawy wprowadzającej lub zaostrzającej odpowiedzialność karną (lex severior retro non agit)" (sygn. akt S 6/91; por. także wyroki 
TK: z dnia 19 lipca 2011 r., sygn. akt K 11/10; z dnia 14 grudnia 2011 r., sygn. akt SK 42/09).

Ustawa powinna przy tym w sposób precyzyjny, niebudzący jakichkolwiek wątpliwości, pozwolić na wskazanie czynu zabronionego i definiować wszystkie jego znamiona wyznaczające cechy tworzące zarys typu przestępstwa. W nauce prawa wskazuje się, że zasada nullum crimen sine lege, nulla poena sine lege wywiera wpływ na prawo karne na trzech płaszczyznach: stanowienia prawa - jako skierowany do prawodawcy postulat ustawowego określenia zagrożenia sankcją karną; jego stosowania - w postaci adresowanego do sądu nakazu wymierzenia tylko takiej kary, jaka została ustawowo przewidziana; jego wykonywania - jako postulat ścisłego określania sposobu egzekwowania kary i wykonania jedynie kary oznaczonej przez orzekający w sprawie sąd (zob. B. Banaszak, Konstytucja Rzeczypospolitej Polskiej. Komentarz, Warszawa 2012, komentarz do art. 42, s. 275). Na podobnym stanowisku stoi Trybunał Konstytucyjny, stwierdzając: „Zasada nullum crimen, nulla poena sine lege kreuje jedno z podstawowych praw człowieka. Wynikają z niej postulaty skierowane zarówno do ustawodawcy, jak i do podmiotów stosujących prawo" (zob. wyrok TK z dnia 16 marca 2011 r., sygn. akt K 35/08). Przepisy prawa karnego powinny zatem mieć cechy precyzyjności, jasności oraz legislacyjnej poprawności, gwarantujące ich komunikatywność wobec adresatów (zob.: orzeczenie TK z dnia 26 kwietnia 1995 r., sygn. akt K 11/94; wyroki TK: z dnia 19 lipca 2011 r., sygn. akt K 11/10; z dnia 14 grudnia 2011 r., sygn. akt SK 42/09).

Ponadto art. 42 ust. 1 Konstytucji formułuje dyrektywę określoności przepisów karnych. Zakaz lub nakaz obwarowane sankcją karną muszą być sformułowane ściśle, zgodnie z zasadą nullum delictum sine lege certa (zob. J. Warylewski, Zasady techniki prawodawczej. Komentarz do rozporzadzenia, Warszawa 2003, s. 326). Brak precyzji ustawodawcy stwarza szerokie pole dla dowolności działania organów stosujących prawo, a to istotnie zwiększa ryzyko bezpodstawnego stosowania sankcji. Podobny pogląd wyraził Trybunał Konstytucyjny, głosząc, że należy wykluczyć niedoprecyzowanie jakiegokolwiek elementu normy karnej, które pozwalałoby na dowolność jej stosowania przez właściwe organy władzy publicznej czy na zawłaszczenie przez te organy pewnych sfer życia i penalizowanie zachowań, które nie zostały expressis verbis określone jako zabronione w przepisie prawa karnego (zob. wyrok TK z dnia 5 maja 2004 r., sygn. akt P 2/03). Jeżeli na skutek braku precyzji ustawodawcy pojawią się wątpliwości dotyczące treści normy prawa karnego, nie można stosować takiej wykładni przepisów, która byłaby na niekorzyść sprawcy czynu. Wiąże się z tym zakaz stosowania analogii i wykładni rozszerzającej (zob. wyrok TK z dnia 6 lipca 1999 r., sygn. akt P 2/99). Konstytucja w art. 42 ust. 1 stanowi o czynie zabronionym. Jak zauważa Trybunał Konstytucyjny, „chodzi zatem o konkretne (skonkretyzowane) zachowanie, jakie można przypisać pewnej jednostce. Jakkolwiek zachowanie to może polegać na różnych aktach (działaniu, zaniechaniu), nie budzi wątpliwości, iż na 
gruncie wspomnianego przepisu konieczne jest precyzyjne jego wskazanie (dookreślenie). W konsekwencji jakiekolwiek wskazanie ogólnikowe, umożliwiające daleko idącą swobodę interpretacji co do zakresu znamion czynu zabronionego czy pewnego typu kategorii zachowań, nie może być traktowane jako spełniające wymóg określoności na gruncie art. 42 ust. 1 Konstytucji”.

Z kolei w postanowieniu Trybunału Konstytucyjnego z dnia 13 czerwca 1994 r. (sygn. akt S 1/94) podkreślono, iż „każda regulacja prawna, nawet o charakterze ustawowym, dająca organowi państwowemu uprawnienie do wkraczania w sferę praw i wolności obywatelskich, musi spełniać warunek dostatecznej określoności. Należy przez to rozumieć precyzyjne wyznaczenie dopuszczalnego zakresu ingerencji oraz trybu, w jakim podmiot ograniczony w swoich prawach i wolnościach może bronić się przed nieuzasadnionym naruszeniem jego dóbr osobistych”. „W demokratycznym państwie prawa każda forma naruszenia przez organ państwowy dobra osobistego musi łączyć się z możliwością kontroli zasadności działania organu państwowego" (orzeczenie TK z dnia 19 czerwca 1992 r., sygn. akt U 6/92). Podkreślono przy tym, że w demokratycznym państwie prawa „wymaganie określoności dotyczyć musi zarówno materialnych elementów czynu, jak i elementów kary, tak by czyniło to zadość wymaganiu przewidywalności. Przepisy prawne muszą bowiem stwarzać obywatelowi (podmiotowi odpowiedzialności karnej) możliwość uprzedniego i dokładnego rozeznania, jakie mogą być prawnokarne konsekwencje jego postępowania. Materialne elementy czynu, uznanego za przestępny, muszą więc być zdefiniowane w ustawie (zgodnie z konstytucyjną zasadą wyłączności ustawy) w sposób kompletny, precyzyjny i jednoznaczny". Wymóg określoności został również wyeksponowany w orzeczeniu Trybunału Konstytucyjnego z dnia 1 marca 1994 r. (sygn. akt U 7/93), w którym wskazano, że niesporne jest, iż w państwie prawnym przepisy karne winny precyzyjnie określać zarówno czyn, jak i karę. Niesporne jest też w świetle konstytucyjnego podziału materii pomiędzy ustawy a akty wykonawcze, że podstawowe elementy zarówno czynu, jak i kary muszą być określone w samej ustawie, a nie mogą być - w sposób blankietowy - pozostawione do unormowania w akcie wykonawczym. Trybunał Konstytucyjny jest zdania, że powyższe konstytucyjne wymagania dotyczące przepisów karnych należy odnosić do wszystkich przepisów o charakterze represyjnym (sankcjonująco-dyscyplinującym), a więc do wszystkich przepisów, których celem jest poddanie obywatela jakiejś formie ukarania czy jakiejś sankcji. Jest to linia orzecznictwa w pełni aktualna pod rządami obecnej Konstytucji. Znajduje ona kontynuację w szeregu wyroków TK, zgodnie z którymi przepisy stanowiące opis czynu zabronionego pod groźbą kary powinny wskazywać adresata nakazu lub zakazu postępowania, którego naruszenie może prowadzić do odpowiedzialności karnej, oraz pozostałe znamiona czynu zabronionego pod groźbą kary, wyznaczające krąg zachowań karalnych, tak aby możliwe było jednoznaczne odróżnienie zachowań zabronionych przez ustawę pod groźbą kary od zachowań niekaralnych oraz odróżnienie poszczególnych ty- 
pów czynów zabronionych (por. wyroki TK: z dnia 26 listopada 2003 r., sygn. akt SK 22/02; z dnia 19 lipca 2011 r., sygn. akt K 11/10; z dnia 17 lipca 2014 r., sygn. akt SK 35/12; z dnia 9 czerwca 2015 r., sygn. akt SK 47/13; z dnia 6 października 2015 r., sygn. akt SK 54/13).

Nie oznacza to jednak, że ustawodawca nie może określać pewnych zachowań stanowiących czyn zabroniony w sposób na tyle ogólny, aby w ich zakresie mieściły się różne działania zabronione np. ze względu na cel, jaki ma być osiągnięty przez ich realizację. Wniosek przeciwny należałoby uznać za absurdalny, w krańcowym bowiem ujęciu prowadziłby do konieczności zaprzeczenia abstrakcyjnego i ogólnego charakteru normy prawnej. Nie może jednak budzić wątpliwości, że jednostka w konkretnych okolicznościach narażona jest na odpowiedzialność karną (zob. wyroki TK: z dnia 26 listopada 2003 r., sygn. akt SK 22/02; z dnia 5 maja 2004 r., sygn. akt P 2/03; z dnia 9 czerwca 2010 r., sygn. akt SK 52/08; z dnia 1 grudnia 2010 r., sygn. akt K 41/07; z dnia 9 października 2012 r., sygn. akt P 27/11; z dnia 27 lutego 2014 r., sygn. akt P 31/13; z dnia 20 maja 2014 r., sygn. akt K 17/13). Trybunał Konstytucyjny zwrócił uwagę, że „standard określoności przepisów prawnych, także w zakresie normowania art. 42 ust. 1 Konstytucji, nie wyklucza posługiwania się w obrębie prawa karnego pewnym marginesem swobody regulacyjnej państwa. Dlatego standard ten w zakresie regulacji penalnej, jakkolwiek stawiający wyższe wymagania ustawodawcy, nie wymaga jasności czy komunikatywności wyrażenia zakazu lub nakazu prawnego w stopniu absolutnym" (wyrok TK z dnia 17 lutego 2015 r., sygn. akt K 15/13). Z zasady nullum crimen sine lege certa nie wynika zaś obowiązek zawarcia w ustawie opisu każdego możliwego zachowania realizującego znamiona czynu zabronionego pod groźbą kary (zob. postanowienie SN z dnia 29 lipca 2009 r., I KZP 8/09, OSNKW 2009, nr 8, poz. 61). Przy ocenie spełnienia konstytucyjnej przesłanki określoności przepisów karnych znaczenie ma także gałąź prawa, której dotyczą sankcjonujące normy karne. Specyfika danej gałęzi może usprawiedliwiać mniejszą precyzję opisu normy prawa karnego, która odnosi się do danej sfery stosunków społecznych, gospodarczych itp.

Zasada określoności czynu zabronionego nie oznacza, że ustalenie znaczenia przepisu określającego znamiona czynu zabronionego nie musi następować w drodze wykładni. Każde ustalenie treści normy na podstawie przepisu jest wynikiem procesu wykładni (por. np. M. Zieliński, Wyznaczniki reguł wykładni prawa, „Ruch Prawniczy, Ekonomiczny i Socjologiczny” 1998, z. 3-4, s. 9 i n. oraz cytowana tam literatura). W związku z tym jako kryterium wystarczającej precyzji przepisów należy traktować odpowiedź na pytanie, czy przepisy umożliwiają jednolitą ich wykładnię w procesie stosowania prawa, dzięki której osiąga się wystarczającą precyzję w konstruowaniu norm prawnych na gruncie tych przepisów (zob. wyrok TK z dnia 14 grudnia 2011 r., sygn. akt SK 42/09). Trybunał Konstytucyjny przyjął, że dyrektywa określoności czynu zabronionego pod groźbą kary jest realizowana wówczas, jeżeli dla adresata normy praw- 
nokarnej, jak i organów stosujących prawo jest oczywiste - przy zastosowaniu powszechnie akceptowanych metod wykładni - to, czy określone zachowanie in concreto wypełnia znamiona tego czynu zabronionego (zob. wyrok TK z 19 lipca 2011 r., sygn. akt K 11/10). Trybunał Konstytucyjny zwrócił uwagę, że nie każda nieostrość czy nie każda niejasność przepisu mogą stanowić podstawę naruszenia zasady nullum crimen sine lege certa, ale jedynie ta, której nie da się usunąć w drodze poprawnych metod wykładni (zob. wyroki TK: z dnia 14 lutego 2012 r., sygn. akt P 20/10; z dnia 9 czerwca 2015 r., sygn. akt SK 47/13; z dnia 22 listopada 2015 r., sygn. akt K 13/15). Do powszechnych metod wykładni przepisów prawa karnego należy w oczywisty sposób wykładnia literalna. Stanowisko Trybunału Konstytucyjnego w sprawie dopuszczalności innych niż literalna metod wykładni nie jest jednolite (za wyłącznością tej metody przemawiają wyroki TK: z dnia 19 lipca 2011 r., sygn. akt K 11/10; z dnia 25 lutego 2014 r., sygn. akt SK 65/12; za dopuszczalnością innych metod wyrok TK z dnia 9 października 2012 r., sygn. akt P 27/11). Sejm opowiada się za wyrażanym obecnie na gruncie teorii prawa stanowiskiem, zgodnie z którym wykładnia literalna nie ma charakteru ani absolutnego, ani nadrzędnego. Jest ona koniecznym etapem interpretacji tekstu normatywnego. Ustalenie jego znaczenia nie może jednak abstrahować od kontekstu, który tworzą: uznawane przez prawodawcę wartości, cele regulacji, społeczna percepcja określonego fragmentu stosunków międzyludzkich itd. Dotyczy to w szczególności tych obszarów życia gospodarczego, w których ze względu na stopień skomplikowania oraz dynamikę zmian jest używany język specjalistyczny, a funkcjonujące w jego ramach znaczenia często odbiegają od typowych znaczeń języka potocznego lub nie znajdują w nim odpowiednika. Wyłączność wykładni literalnej można odnieść do przepisów określających znamiona czynów zabronionych odnoszących się do rzeczywistości naturalnej (np. pozbawienie życia, uszkodzenie ciała). W przypadku, w którym norma karna odwołuje się do złożonej rzeczywistości normatywnej, takiej jak m.in. obrót instrumentami finansowymi, opis znamion czynu zabronionego musi odwoływać się do sposobu właściwego opisowi tej rzeczywistości w aktach normatywnych, a ustalenie znaczenia przepisu karnego powinno być dokonywane z uwzględnieniem metod wykładni właściwych dla obszaru regulacji, z którym związana jest dana norma karna. W kontekście więc prawa rynku kapitałowego oznacza to dopuszczalność m.in. wykładni celowościowej, wykładni systemowej, wykładni „proeuropejskiej” itd.

Sejm zwraca także uwage, że zasada nullum crimen sine lege certa dotyczy określenia znamion czynu zabronionego. Odrębnie należy natomiast potraktować określenie treści kontratypu, czyli dodatkowych okoliczności wyłączających bezprawność zachowania sprawcy, który zrealizował znamiona czynu zabronionego. Sejm stoi na stanowisku, zgodnie z którym istnienie kontratypów pozaustawowych jest konstytucyjnie dopuszczalne. Stanowisko to znajduje potwierdzenie zarówno w orzecznictwie sądów powszechnych, jak i w literaturze prawa 
karnego (por. np. wyroki SN: z dnia 25 stycznia 2000 r., sygn. akt WKN 45/99; z dnia 23 listopada 2010 r., sygn. akt IV KK 173/10; z dnia 9 lipca 2013 r., sygn. akt II KK 152/13; z dnia 5 marca 2015 r., sygn. akt III KK 274/14; uchwały SN: z dnia 20 września 2007 r., sygn. akt I KZP 26/07; z dnia 30 listopada 2016 r., sygn. akt SNO 49/16; postanowienia SN: z dnia 7 stycznia 2008 r., sygn. akt V KK 158/07; z dnia 11 października 2016 r., sygn. akt V KK 117/16; M. Cieślak, Polskie prawo karne. Zarys systemowego ujęcia, Warszawa 1994, s. 218; L. Gardocki, Prawo karne, Warszawa 2007, s. 111). W związku z tym należy przyjąć, że istnienie i regulacja kontratypu nie zostały objęte zakresem normy wynikającej z art. 42 ust. 1 Konstytucji. Nie oznacza to, że w sytuacji, w której kontratyp został uregulowany ustawowo, sposób jego regulacji nie podlega ocenie z punktu widzenia konstytucyjnych kryteriów poprawności legislacyjnej. Kryteria te wynikają z art. 2 Konstytucji.

Zasada określoności przepisów jest jedną z zasad szczegółowych wywodzonych $\mathrm{z}$ art. 2 Konstytucji. Jest ona określana także jako zasada jednoznaczności prawa (por. np. P. Tuleja, komentarz do art. 2 [w:] Konstytucja Rzeczypospolitej Polskiej. Komentarz, t. I, red. M. Safjan, L. Bosek, Warszawa 2016, nb. 27). Pozostaje także w ścisłym związku z szerzej pojmowaną zasadą przyzwoitej legislacji (por. wyrok TK z dnia 4 maja 2004 r., sygn. akt K 40/02). W wyroku z dnia 11 stycznia 2000 r. (sygn. akt K 7/99) TK stwierdził, że zasada ta obejmuje m.in. „wymaganie określoności przepisów, które muszą być formułowane w sposób poprawny, precyzyjny i jasny”, a „standard ten wymagany jest zwłaszcza, gdy chodzi o ochronę praw i wolności" (por. także wyroki TK: z dnia 17 października 2000 r., sygn. akt SK 5/99; z dnia 21 marca 2001 r., sygn. akt K 24/00; z dnia 12 czerwca 2002 r., sygn. akt P 13/01; z dnia 27 kwietnia 2004 r., sygn. akt K 24/03; z dnia 28 lutego 2008 r., sygn. akt K 43/07; z dnia 13 października 2010 r., sygn. akt Kp 1/09; z dnia 27 października 2010 r., sygn. akt K 10/08; z dnia 6 października 2015 r., sygn. akt SK 54/13; z dnia 18 kwietnia 2018 r., sygn. akt K 52/16). Interpretując wymóg określoności przepisów prawa, TK wskazał w wielu rozstrzygnięciach, że wynika z niego postulat poprawnego skonstruowania przepisów z punktu widzenia językowego i logicznego. Wymóg jasności oznacza nakaz tworzenia przepisów klarownych i zrozumiałych dla ich adresatów, którzy od racjonalnego ustawodawcy mogą oczekiwać stanowienia norm prawnych niebudzących wątpliwości co do treści nakładanych obowiązków i przyznawanych praw (por. np. wyroki TK: z dnia 22 maja 2002 r., sygn. akt K. 6/02; z dnia 27 lipca 2006, sygn. akt SK 43/04; z dnia 21 kwietnia 2009 r., sygn. akt K 50/07; z dnia 8 grudnia 2009 r., sygn. akt K 7/08). Trybunał Konstytucyjny wskazał jednocześnie, że wymóg określoności przepisów nie jest równoznaczny z wymogiem wymieniania $\mathrm{w}$ tekście przepisu expressis verbis wszystkich konsekwencji wynikającej z niego normy. Zasada ta dopuszcza wszelkie wnioskowania, które mieszczą się w przyjętej metodologii wykładni tekstu prawnego. Z zasadą tą nie jest sprzeczne w szczególności zastosowanie analogii (por. np. wyrok TK z dnia 18 kwietnia 2018 r., sygn. akt K 52/16). Zasadzie określoności przepisów prawa 
nie sprzeciwia się także zastosowanie klauzul generalnych, których szczegółowa treść i sposób zastosowania są wynikiem dorobku orzecznictwa (por. np. wyrok TK z dnia 17 października 2000 r., sygn. akt SK 5/99).

Zasada określoności przepisów jest przejawem szerszej zasady zaufania obywateli do państwa i stanowionego przez nie prawa. Fakt obowiązywania przepisów o niejasnej treści umożliwia bowiem organom państwa zastępowanie ustawodawcy w zakresie tych zagadnień, które uregulował on w sposób nieprecyzyjny. Trybunał Konstytucyjny w wyroku z dnia 22 maja 2005 r. (sygn. akt K 6/02) podkreślił, że „ustawodawca nie może poprzez niejasne formułowanie tekstu przepisów pozostawiać organom mającym je stosować nadmiernej swobody przy ustalaniu w praktyce zakresu podmiotowego i przedmiotowego ograniczeń konstytucyjnych wolności i praw jednostki". Zgodnie ze stanowiskiem wyrażanym w orzecznictwie TK oraz doktrynie prawa konstytucyjnego zasada zaufania nie tylko jest podstawą obowiązywania innych zasad konstytucyjnych (m.in. poprawnej legislacji), ale ma też własną treść normatywną (por. np. P. Tuleja, op. cit., nb. 25). Zastosowanie tej zasady tworzy podstawowy w demokratycznym państwie prawnym standard ochrony bezpieczeństwa prawnego jednostki. Stąd określa się ją zasadą lojalności państwa względem obywateli (ibidem). W wyroku z dnia 7 lutego 2001 r. (sygn. akt K 27/00) TK stwierdzil, że z zasady lojalności państwa względem obywatela wynika, „by nie stawało się ono swoistą pułapką dla obywatela i aby mógł on układać swoje sprawy w zaufaniu, iż nie naraża się na prawne skutki, których nie mógł przewidzieć w momencie podejmowania decyzji i działań oraz w przekonaniu, iż jego działania podejmowane zgodnie $\mathrm{z}$ obowiązującym prawem będą także w przyszłości uznawane przez porządek prawny”. Zasada zaufania wiąże się w związku z tym z kryterium pewności prawa. Jest ono rozumiane jako kluczowy element bezpieczeństwa prawnego jednostki, które umożliwia jej decydowanie o swoim zachowaniu w oparciu o wszystkie relewantne i znane jej przesłanki potencjalnej reakcji organów państwa, co w konsekwencji oznacza znajomość konsekwencji prawnych, jakie to zachowanie jednostki może pociągnąć (zob. wyroki TK: z dnia 14 czerwca 2000 r., sygn. akt P 3/00; z dnia 19 listopada 2008 r., sygn. akt KP 2/08; z dnia 20 stycznia 2009 r., sygn. akt P 40/07; z dnia 24 lutego 2010 r., sygn. akt K 6/09; P. Tuleja, op. cit., nb. 25). Zasada zaufania do państwa i stanowionego przez nie prawa odnosi się w znacznej mierze do trybu i formy stanowionego prawa (por. np. wyrok TK z dnia 4 listopada 2015 r., sygn. akt K 1/14). Jej znaczenie nie wyczerpuje się jednak na tym etapie relacji między państwem a osobami podlegającymi jego władzy. Jej elementem obok wymienionej wyżej zasady określoności przepisów jest także zakaz tworzenia nieracjonalnych ograniczeń w korzystaniu z praw przez obywateli (por. np. w odniesieniu do terminów wyroku TK z dnia 19 kwietnia 2005 r. sygn. akt 4/05; także W. Sokolewicz, M. Zubik, komentarz do art. 2 [w:] Konstytucja Rzeczypospolitej Polskiej. Komentarz, t. I, red. L. Garlicki, M. Zubik, Warszawa 2016, s. 129). 


\section{Ocena zgodności}

1. Opis czynu zabronionego zawarty w art. 183 ust. 1 u.o.i.f. w pierwotnym brzmieniu pozwala na gruncie wykładni językowej na jednoznaczną konkluzję, że przestępstwo manipulacji instrumentem finansowym może polegać na wprowadzeniu lub zagrożeniu wprowadzeniem w błąd co do popytu lub podaży bez wprowadzenia w błąd co do rzeczywistej ceny instrumentu finansowego. Artykuł 183 ust. 1 u.o.i.f. w pierwotnym brzmieniu, opisując znamiona czynu zabronionego, odsyłał do definicji manipulacji zawartej w art. 39 ust. 2 pkt 1 u.o.i.f. Przepis ten definiował manipulację jako m.in. składanie zleceń lub zawieranie transakcji „wprowadzających lub mogących wprowadzić w błąd co do rzeczywistego popytu, podaży lub ceny instrumentu finansowego”. Posłużenie się spójnikiem „lub” na gruncie języka i logiki wskazuje na alternatywny charakter znamion czynu zabronionego. Wynika stąd, że sprawca popełnia czyn zabroniony, jeżeli spełni przynajmniej jedną z przesłanek. Wprowadzenie w błąd lub zagrożenie wprowadzeniem w błąd co do rzeczywistego popytu lub podaży wystarcza do spełnienia znamion czynu zabronionego, nawet jeżeli zachowanie sprawcy nie wprowadziło i nie mogło wprowadzić w błąd co do rzeczywistej ceny instrumentu. Wniosek dotyczący alternatywnego charakteru przesłanek wprowadzenia lub narażenia na wprowadzenie w błąd co do popytu, podaży lub ceny instrumentu finansowego nie był także kwestionowany w literaturze polskiej (T. Sójka, komentarz do art. 39 u.o.i.f. [w:] Prawo rynku kapitałowego. Komentarz, red. T. Sójka, Warszawa 2015, teza 12; C. Martysz, Manipulacje instrumentami finansowymi i insider trading. Analiza prawno-ekonomiczna, Warszawa 2015, s. 68; J. Bojarski, M. Kalinowski, Składanie zleceń lub dokonywanie transakcji na rynku w celu dokonania optymalizacji podatkowej a manipulacja karalna na podstawie art. 183 ust. 1 ustawy o obrocie instrumentami finansowymi, „Studia Iuridica Toruniensia” 2016, t. XVIII, nr 1, s. 30; A. Błachnio-Parzych, komentarz do art. 39 u.o.i.f. [w:] Prawo rynku kapitałowego, red. M. Wierzbowski, Warszawa 2014, nb. 6; K. Korn, Pojęcie manipulacji instrumentami finansowymi, cz. 2, „Transformacje Prawa Prywatnego” 2012, z. 4, s. 33-34). Artykuł 39 ust. 2 pkt 1 u.o.i.f. stanowił transpozycję do polskiego prawa art. 1 ust. 2 lit. a dyrektywy Parlamentu Europejskiego i Rady 2003/6/WE z dnia 28 stycznia 2003 r. w sprawie wykorzystywania poufnych informacji i manipulacji na rynku (nadużyć na rynku) (Dz. Urz. UE L 96 z 12.04.2003, s. 16, ze zm.). Przepis dyrektywy wskazuje także jednoznacznie, że manipulacją jest „zawieranie transakcji lub składanie zleceń, które dają, lub prawdopodobnie dawałyby, fałszywe lub wprowadzające w błąd sygnały dotyczące podaży, popytu lub ceny instrumentów finansowych". Na gruncie tego przepisu także w literaturze dotyczącej prawa europejskiego oraz prawa innych państw członkowskich nie budziło wątpliwości to, że manipulacją mogą być transakcje wprowadzające lub mogące wprowadzić w błąd wyłącznie w odniesieniu do rzeczywistego popytu lub podaży (por. np. G. Walker, R. Purves, Financial Services Law, Oxford 2018, s. 481; W. Wehowsky, $\$ 20$ a WpHG [w:] Strafrechtliche Nebengesetze, red. 
G. Erbs, M. Kohlhaas, München 2012; nb. 27; E. Schwark, \$20a WpHG [w:] Kapitalmarktrechts-Kommentar, red. E. Schwark, D. Zimmer, Monachium 2010, nb. 38; S. Vicenzi, Gli abusi del mercato, Trento 2012, s. 46; A. Worms, Verbot der Marktmanipulation [w:] Handbuch des Kapitalanlagerechts, red. H.D. Assman, R.A. Schütze, München 2015, nb. 102).

2. Sejm zauważa także, że nieścisłe merytorycznie są zarzuty skarżących odnoszące się do braku transpozycji do prawa polskiego dyrektywy Komisji 2003/124/WE z dnia 22 grudnia 2003 r. wykonującej dyrektywę Parlamentu Europejskiego i Rady 2003/6/WE w zakresie definicji i publicznego ujawniania informacji wewnętrznych oraz definicji manipulacji na rynku (Dz. Urz. UE L 339 z 24.12.2003, s. 70; dalej: dyrektywa Komisji). Po pierwsze, w tej dyrektywie Komisja wyraźnie wskazuje, że wymienione w art. 4 zachowania mają charakter wyliczenia przykładowego oraz powinny być stosowane bez uszczerbku dla definicji manipulacji z art. 1 pkt 2 lit. a dyrektywy 2003/6/WE. Skarżący w sposób nieuprawniony wyciągają z treści tego przykładowego wykazu wnioski zawężające językowe rozumienie definicji manipulacji zawarte art. 1 pkt 2 lit. a dyrektywy 2003/6/WE, z którego wynika jednoznacznie, że znamiona wprowadzenia w błąd co do popytu, podaży lub ceny mają charakter alternatywny, a więc że nie każdy przypadek manipulacji transakcyjnej musi polegać na wprowadzeniu lub zagrożeniu wprowadzeniem w błąd co do ceny instrumentów finansowych. Po drugie, zarzut braku transpozycji art. 4 dyrektywy Komisji do prawa polskiego pozostaje bez związku z zarzutem naruszenia art. 42 ust. 1 Konstytucji. Nawet gdyby uznać, że przepisy dyrektywy Komisji rzeczywiście nie zostały prawidłowo transponowane, nie oznacza to, że redakcja zaskarżonego przepisu narusza zasadę nullum crimen sine lege certa.

3. Sejm nie podziela także zdania skarżących, zgodnie z którym nieprawidłowym zabiegiem przy definiowaniu znamion czynu zabronionego jest odróżnienie rzeczywistego popytu lub podaży od sztucznego popytu i podaży. W literaturze wyraźnie wskazuje się, że naturalnym motywem transakcji na rynku instrumentów finansowych jest realizacja inwestycji w celu osiągnięcia zysku. Transakcje, których celem nie jest zwiększenie wartości majątku inwestora w wyniku wzrostu wartości inwestycji lub realizacji innych przychodów wynikających z nabytych praw, ale wywarcie wpływu na kształt rynku, mają charakter sztuczny i mogą być kwalifikowane jako manipulacja przy jednoczesnym spełnieniu innych przesłanek (por. np. W. Wehowsky, op. cit., nb. 22). W ekonomii transakcyjnej podkreśla się, że normalnym mechanizmem transakcji rynkowej są zróżnicowane oceny dotyczące wartości wymienianych dóbr. Cena w transakcji jest wynikiem sytuacji, w której sprzedawane dobro jest dla sprzedawcy (subiektywnie) mniej wartościowe niż cena, którą otrzymuje w zamian za dobro. Jednocześnie kupujący wycenia subiektywnie nabywane dobro powyżej wartości ceny, którą za to dobro płaci. W zwykłym układzie interesów i motywacji dobra przechodzą od podmiotów, które przypisują im niższą wartość, do podmiotów, które przypisują im 
wartość wyższą (por. np. J. Stelmach, B. Brożek, W. Załuski, Dziesięć wykładów o ekonomii prawa, Warszawa 2007, s. 111; B.E. Hermalin, A.W. Katz, R. Craswell [w:] Handbook of Law and Economics, t. I, red. A.M. Polinsky, S. Shavell, Amsterdam 2007, s. 24 i n.). Uproszczenie, standaryzacja oraz automatyzacja procedur zawierania umów na zorganizowanym rynku kapitałowym uwypuklają aktualność przedstawionego wyżej modelu wymiany. Z tego względu wyodrębnienie kategorii transakcji, w których strony nie dążą do osiągnięcia korzyści z inwestycji i których przyczyną nie są zróżnicowane oceny dotyczące zbywanych walorów, ale dążenie do wywołania określonego wyobrażenia o stanie rynku, w tym o wielkości popytu i podaży na zbywane aktywa, można uznać za odrębną kategorię operacji rynkowych, która powinna podlegać krytycznej ocenie prawodawcy, jeżeli zagraża ładowi informacyjnemu na rynku. Do istoty manipulacji transakcyjnej rzeczywiście należy brak możliwości odróżnienia transakcji manipulacyjnej od zwykłych transakcji rynkowych na podstawie zewnętrznych cech samej transakcji. Transakcje, które zewnętrznie różniłyby się od zwykłych operacji rynkowych, byłyby identyfikowalne dla pozostałych uczestników obrotu i nie mogłyby wprowadzić ich w błąd. Tym, co odróżnia manipulację transakcyjną od legalnych transakcji rynkowych, jest jej strona podmiotowa. O bezprawności działań autora manipulacji decydują zamiar wywarcia wpływu na cenę, zamiar wprowadzenia w błąd inwestorów oraz dążenie do osiągnięcia korzyści w wyniku tych działań (por. np. M. Spyra [w:] System prawa handlowego, t. IV, red. M. Stec, Warszawa 2016, s. 54-55). Odwołanie się w konstruowaniu typu czynu zabronionego do podmiotowej strony działania sprawcy (przede wszystkim zamiaru) jest zwyczajnym zabiegiem legislacyjnym w prawie karnym. Nie ma zatem podstaw do stwierdzenia, że zaskarżony przepis jest sprzeczny z art. 42 ust. 1 Konstytucji ze względu na zdefiniowanie czynu zabronionego za pomocą znamion odnoszących się do zamiaru sprawcy.

O naruszeniu zasady nullum crimen sine lege certa nie świadczy także brak wskazania w zaskarżonym przepisie kręgu osób, które zostają lub mogą zostać wprowadzone w błąd manipulacyjnymi transakcjami. Czyn opisany w zaskarżonym przepisie miał charakter formalnego przestępstwa narażenia dobra prawnego („wprowadzających lub mogących wprowadzić w błąd”). Jego popełnienie nie wymagało wywołania u konkretnej osoby błędnego wyobrażenia o rzeczywistym popycie lub podaży na dany instrument finansowy. Znamiona czynu zabronionego spełniało samo powstanie stanu zagrożenia wywołaniem takiego błędu. Sejm zauważa, że szkodliwość społeczna takiego zachowania dotyczy możliwości wywołania błędu zarówno u osób, które zainwestowały w instrumenty finansowe będące przedmiotem manipulacji, jak i u osób będących dopiero potencjalnymi inwestorami. Konstrukcja typu czynu zabronionego zastosowana w zaskarżonym przepisie była analogiczna do opisu znamion innych przestępstw abstrakcyjnego narażenia. W przestępstwach tych do realizacji znamion danego typu wystarczy podjęcie - określonego jako znamię czynnościowe - zachowania sprawcy, które 
potencjalnie pociąga za sobą niebezpieczeństwo dla dobra prawnego. Dobrem chronionym w przypadku karnoprawnych mechanizmów przeciwdziałania manipulacji na rynku instrumentów finansowych nie jest w pierwszym rzędzie indywidualny interes konkretnych inwestorów aktywnych na rynku, ale stanowią go przede wszystkim efektywność i integralność rynku instrumentów finansowych jako abstrakcyjne dobro prawne (por. np. A. Worms, op. cit., nb. 76; M. Spyra, op. cit., s. 56; D. Ziouvas, T. Walter, Das neue Börsenstrafrecht mit Blick auf das Europarecht - zur Reform des $\$ 88$ BörsG, „Wertpapiermitteilungen” 2002, Nr. 29, s. 1488). Z tego względu nie jest konieczne precyzowanie w opisie typu czynu zabronionego kręgu osób narażonych na wprowadzenie w błąd przez działania sprawcy. Nie jest potrzebne także sprecyzowanie ich poziomu wiedzy oraz doświadczenia jako inwestorów na rynku. Okoliczności te podlegają wykładni na ogólnych zasadach właściwych wykładni przepisów prawa karnego konstruujących typy czynów zabronionych i posługujących się konstrukcją konkretnego lub abstrakcyjnego zagrożenia (por. np. E. Hryniewicz, Przestępstwa abstrakcyjnego i konkretnego zagrożenia dóbr prawnych, Warszawa 2012, s. 251 i n.). Sejm zwraca uwagę na okoliczność, że zwykłą praktyką konstruowania w polskim prawie karnym typów czynów zabronionych odwołujących się do konstrukcji zagrożenia dobra prawnego jest niedefiniowanie kategorii ani cech osób narażonych na niebezpieczeństwo. Przykładem takiego przepisu jest art. 174 k.k., definiujący przestępstwo sprowadzenia bezpośredniego niebezpieczeństwa katastrofy w ruchu lądowym, wodnym lub powietrznym. Pojęcie katastrofy odnosi się do zdarzenia w komunikacji pociągającego za sobą bezpośrednie niebezpieczeństwo dla życia lub zdrowia wielu osób albo mienia w wielkich rozmiarach (por. np. G. Bogdan, komentarz do art. 173 [w:] Kodeks karny. Komentarz, red. W. Wróbel, A. Zoll. Warszawa 2017, uw. 12). Kodeks karny nie definiuje liczby osób narażonych działaniem sprawcy wymaganej do zakwalifikowania zdarzenia jako katastrofy. Nie definiuje także poziomu wiedzy, umiejętności i doświadczenia uczestników zdarzenia, chociaż okoliczności te nie pozostają bez wpływu na ocenę, czy zachowanie sprawcy naraziło innych uczestników zdarzenia. Powyższe okoliczności są ustalane w drodze wykładni w procesie stosowania prawa. Te same uwagi można odnieść np. do konstrukcji art. 164, art. 165, art. $166 \$ 2$ i art. $171 \$ 1$ k.k. Zdaniem Sejmu dokładność opisu czynu zabronionego w zaskarżonym przepisie spełnia standardy przyjęte $\mathrm{w}$ polskim prawie karnym i nie narusza w związku z tym art. 42 ust. 1 Konstytucji.

4. Jako nietrafne należy także ocenić zarzuty skarżących odnoszące się do redakcji art. 39 ust. 2 pkt 1 u.o.i.f. w części określającej okoliczności uchylające bezprawność działania sprawcy. Wykładnia określenia „uprawniony” użytego w polskiej ustawie mogła i powinna być dokonana w zgodności z prawem europejskim. Jest zatem oczywiste, że ustalając znaczenie pojęcia „uprawnionego" na gruncie zaskarżonego przepisu nie można mu było nadać innego znaczenia niż znaczenie sformułowania „zgodny z prawem”, użytego w art. 1 pkt 2 lit. a dyrek- 
tywy 2003/6/WE (por. szerzej na temat wykładni zgodnej z prawem europejskim A. Sołtys, Obowiązek wykładni zgodnej w orzecznictwie Trybunału Konstytucyjnego, cz. 1, „Europejski Przegląd Sądowy” 2014, nr 4, s. 4 i n.). Zdaniem Sejmu skarżący nadają nadmierne znaczenie różnicom między określeniem „uprawniony” a określeniem „zgodny z prawem”. W kontekście przepisu określającego znamiona czynu zabronionego oraz okoliczności wyłączające bezprawność działania sprawcy „uprawnienie” do określonego działania musi mieć charakter prawny. Sejm podziela także stanowisko dotyczące problemu konstytucyjności definicji manipulacji transakcyjnej prezentowane na gruncie porządków prawnych innych państw członkowskich. W literaturze niemieckiej wyraża się np. zapatrywanie, zgodnie z którym o zachowaniu zasady nullum crimen sine lege certa decyduje precyzyjne i proste opisanie pozytywnych znamion decydujących o bezprawności czynu. Znamiona odnoszące się do okoliczności decydującej o bezprawności manipulacji zostały w prawie europejskim opisane za pomocą jasnych kategorii, takich jak błąd, popyt, podaż i cena. Kategorie bardziej złożone, takie jak uprawniony charakter działania lub ustalone praktyki rynkowe, zawężały zakres bezprawności, a w związku z tym zastosowania sankcji karnej. Ze względu na szybko rozwijające się techniki obrotu na rynku oraz inne nowe zjawiska na rynku instrumentów finansowych nie można oczekiwać, że ustawodawca będzie w stanie opisać szczegółowo wszystkie sposoby dokonywania manipulacji oraz wszystkie praktyki rynkowe decydujące o dopuszczalności zachowania sprawcy (A. Worms, op. cit., nb. 74; J. Vogel, \$22a WpHg [w:] Wertpapierhandelsrecht. Kommentar, red. H.D. Assmann, U.H. Schneider, Köln 2012, nb. 29). Ten pogląd należy uznać za zgodny z stanowiskiem dotyczącym standardu przejrzystości przepisów prawa karnego wyrażonym przez polski TK. W wyroku z dnia 9 czerwca 2010 r. (sygn. akt SK 52/08) TK wskazał, że nakaz określoności (nullum crimen sine lege) odnosi się do „zasadniczych znamion czynu zabronionego". Jednocześnie - zgodnie ze stanowiskiem wyrażonym w wyroku z dnia 25 lutego 2014 r. (sygn. akt SK 65/12) - TK wskazał m.in., że zasady nullum crimen sine lege certa nie narusza zastosowanie przez ustawodawcę zwrotów niedookreślonych lub nieostrych, jeżeli ich znaczenie można ustalić za pomocą językowych reguł wykładni, które nie są stosowane arbitralnie ad casum oraz których zastosowanie podlega kontroli w ramach gwarancji proceduralnych, zapewniających przejrzystość i ocenność praktyki wypełniania takich zwrotów konkretną treścią przez organy państwa, a także jeżeli ewentualne rozbieżności w zastosowaniu zwrotów ocennych dają się usunąć środkami służącymi eliminowaniu niejednolitości stosowania prawa, takimi jak kontrola instancyjna czy podejmowanie uchwał wyjaśniających zagadnienia prawne przez Sąd Najwyższy. Zdaniem Sejmu zaskarżony przepis spełnia określone w ten sposób kryteria. Penalizacja transakcji mogących wprowadzić w błąd co do wysokości popytu lub podaży przy jednoczesnym braku wątpliwości dotyczących ceny wynika wprost z językowej wykładni przepisu. Ta kwestia nie podlega arbitralnej wykładni 
ad casum. Jednocześnie zarówno polska procedura karna, jak i wynikająca z prawa europejskiego procedura postępowania przed Trybunałem Sprawiedliwości zapewniają odpowiednie gwarancje proceduralne oraz środki kontroli pozwalające na wyeliminowanie ewentualnych rozbieżności w zastosowaniu zaskarżonego przepisu.

5. Sformułowane powyżej argumenty przemawiające za zgodnością zaskarżonych przepisów z wynikającą $\mathrm{z}$ art. 42 ust. 1 Konstytucji zasadą nullum crimen sine lege certa należy odnieść także do zarzutów naruszenia zasad określoności przepisów oraz zaufania do państwa i stanowionego przez nie prawa, wynikających $\mathrm{z}$ art. 2 Konstytucji. Jak wskazano to wyżej, na gruncie zarówno wykładni językowej, jak i wykładni celowościowej nie istniały wątpliwości dotyczące okoliczności, że transakcje mogące wprowadzić w błąd co do wielkości popytu lub podaży należy zakwalifikować jako manipulację instrumentami finansowymi, nawet jeżeli nie mogą one wprowadzić w błąd co do ceny instrumentów finansowych. Redakcja kwestionowanego przez skarżących przepisu była przejrzysta. Nie uchybiała ona ani zasadom logiki, ani zasadom poprawnej polszczyzny. Odwołanie się przy zdefiniowaniu okoliczności wyłączających bezprawność działania sprawców do ogólnej klauzuli „uprawnionych powodów” należy traktować jako posłużenie się klauzulą generalną, co w świetle poglądów wyrażonych przez TK w wyroku z dnia 17 października 2000 r. (sygn. akt SK 5/99) nie narusza zasady określoności przepisów. $Z$ tego względu należy także odrzucić jako nietrafne zarzuty dotyczące naruszenia zasady zaufania do państwa i stanowionego przez nie prawa. Zaskarżone przepisy nie uzasadniały w jakikolwiek sposób przekonania skarżących, że ich działanie jest legalne. Co więcej, jak wynika z faktycznych ustaleń sądów rozpoznających sprawy karne skarżących, mieli oni pełną świadomość, że dokonywane przez nich transakcje nie mają służyć przeniesieniu własności instrumentów finansowych za wynagrodzeniem (ostatecznie stan portfeli skarżących nie uległ zmianie), a jedynie zawyżeniu statystyki obrotów akcjami spółki Boryszew w celu utrudnienia lub uniemożliwienia wejścia na jej miejsce w skład indeksu WIG20 innego podmiotu. Brak jest zatem podstaw, aby przyjąć, że zaskarżone przepisy wprowadziły skarżących w błąd oraz że ich treść skłoniła ich do podjęcia inkryminowanych działań. Jako nietrafny należy uznać także zarzut przypisania skarżącym ujemnych konsekwencji nieefektywnego nadzoru nad działalnością giełdy papierów wartościowych w zakresie ustanawiania norm wiążących ich użytkowników. Po pierwsze, skarżący nie wykazali, aby takie braki w nadzorze miały miejsce. Po drugie, jak wskazano to wyżej, skarżący nietrafnie powołują się na postanowienia aktów wewnętrznych Giełdy Papierów Wartościowych w Warszawie dotyczących transakcji typu „cross” jako źródła ich przekonania o legalności ich inkryminowanych działań. Szczegółowe zasady obrotu giełdowego ( $\$ 36 \mathrm{i} \mathrm{n}$.) określają proceduralny aspekt transakcji „cross”, przesądzając m.in. o możliwości sprzedaży instrumentów finansowych między dwoma konkretnymi inwestorami będącymi klientami tego samego członka giełdy. Nie 
odnoszą się jednak w jakikolwiek sposób do celów takiego działania. Nie zawierają także postanowień uzasadniających przypuszczenia, że wielokrotna wzajemna sprzedaż i zakup tych samych instrumentów finansowych mogąca wywołać fałszywe wyobrażenie o wielości popytu lub podaży jest działaniem zgodnym $z$ prawem i nie nosi znamion manipulacji. Manipulacja transakcyjna jest $z$ natury rzeczy działaniem podejmowanym przede wszystkim na zorganizowanym rynku instrumentów finansowych (w tym na giełdzie papierów wartościowych). Popełnienie tego czynu wymaga więc realizacji transakcji przeprowadzonych zgodnie z regulaminem oraz szczegółowymi zasadami obrotu obowiązującymi na danym rynku zorganizowanym. Proceduralna („techniczna”) poprawność tych transakcji nie przesądza jednak w jakikolwiek sposób o ich legalności w sytuacji, w której skutkiem tych działań może być wprowadzenie w błąd innych inwestorów. Niezależnie od tych rozważań należy także zauważyć, że ewentualna wadliwość szczegółowych zasad obrotu oraz wadliwość publicznego nadzoru nad rynkiem regulowanym nie są okolicznościami, które można wywodzić z zaskarżonych przepisów. Nie mają one zatem znaczenia dla oceny, czy sposób ich sformułowania przez ustawodawcę oraz ich zastosowania przez sądy narusza zasadę zaufania obywateli do państwa i stanowionego przez nie prawa.

6. W związku z powyższym Sejm wnosi o stwierdzenie, że art. 183 ust. 1 u.o.i.f. w pierwotnym brzmieniu obowiązującym przed 6 maja 2017 r. w związku z art. 39 ust. 2 pkt 1 u.o.i.f., uchylonym nowelizacją z 2017 r., w zakresie, w jakim pozwala uznać za czyn zabroniony pod groźbą kary składanie zleceń lub zawieranie transakcji zgodnych ze szczególnymi regulacjami ustalonymi dla obrotu giełdowego przez spółkę prowadzącą rynek regulowany dokonywanych między akcjonariuszami notowanej na giełdzie spółki, które to zlecenia lub transakcje wpływają na wielkość obrotu akcjami spółki i mogą wpływać na pozycję spółki w publikowanych przez spółkę prowadzącą rynek regulowany indeksach, lecz nie wprowadzają lub nie mogą wprowadzać innych inwestorów w błąd co do ceny akcji, jest zgodny z art. 42 ust. $1 \mathrm{w}$ związku z art. 2 Konstytucji.

\section{Zarzut naruszenia art. 64 ust. 1 w związku z art. 2 Konstytucji}

\section{Zarzuty skarżących}

Skarżący zarzucają, że art. 183 ust. 1 u.o.i.f. ingeruje w sposób nieproporcjonalny w konstytucyjne prawo własności, ponieważ zakazuje pod groźbą kary rozporządzania akcjami przez akcjonariusza w celu niepogorszenia wizerunku spółki, której akcjami się rozporządza.

Zdaniem skarżących art. 183 ust. 1 w związku z art. 39 ust. 2 pkt 1 u.o.i.f. penalizuje działania, które dokonywane są bez uzyskiwania korzyści kosztem innych inwestorów. Elementem tego prawa jest uprawnienie do rozporządzania instrumentami finansowymi zgodnie $\mathrm{z}$ zasadami uczciwego obrotu. W pojęciu uczciwego obrotu mieszczą się wszelkie działania, które nie przynoszą uczestni- 
kowi obrotu nieakceptowanych społecznie korzyści osiąganych kosztem innych uczestników obrotu. Zdaniem skarżących działania, które wpływały na poziom obrotu akcjami, ale nie na cenę akcji, nie przynoszą skarżącym korzyści osiąganych kosztem innych inwestorów giełdowych. Działania takie, zdaniem skarżących, nie są szkodliwe społecznie. Ich penalizacja ma zatem nie znajdować usprawiedliwienia w świetle zasady proporcjonalności norm prawa karnego oraz ogólnej zasady proporcjonalności obowiązującej w demokratycznym państwie prawa i ma także tym samym pozostawać w sprzeczności $z$ art. 21 ust. 1 Konstytucji, jako nieuzasadniona ingerencja w istotę tego prawa.

Naruszenie konstytucyjnego prawa własności ma również wynikać z nałożenia na skarżących w wyroku karnym obowiązku świadczenia pieniężnego na rzecz określonego podmiotu. Skarżący formułują przy tym szczegółowe zarzuty nie wobec wysokości sankcji karnej, ale w stosunku do jej zastosowania w ogólności.

\section{- 2. Wzorzec konstytucyjny}

1. Artykuł 21 Konstytucji statuuje zasadę ustrojową, zgodnie z którą Rzeczpospolita Polska chroni własność i prawo dziedziczenia. Zasady ustrojowe, takie jak ta wyrażona w art. 21 Konstytucji, mają kluczowe znaczenie w perspektywie poszukiwania wzorca konstytucyjnego w zakresie dotyczącym badania konstytucyjności kwestionowanych przepisów prawnych, jeśli Konstytucja nie zawiera norm bardziej szczegółowych. W zakresie dotyczącym ochrony prawa własności oraz ograniczonych praw rzeczowych takie szczegółowe normy zawiera art. 64 Konstytucji. Jak wskazano to wyżej w proceduralnej części analizy (punkt III.3 stanowiska), z punktu widzenia postępowania w przedmiocie skargi konstytucyjnej właściwym wzorcem kontroli nie jest przepis Konstytucji o charakterze ustrojowym, ale jest nim przepis konstytuujący własność i inne prawa majątkowe jako prawa konstytucyjne.

2. W orzecznictwie Trybunału Konstytucyjnego na tle art. 64 ust. 1, a także art. 21 ust. 1 Konstytucji ugruntowany jest pogląd, że „na ustawodawcy pozytywnym spoczywa nie tylko obowiązek pozytywny stanowienia przepisów i procedur udzielających ochrony prawnej prawom majątkowym, ale także obowiązek negatywny powstrzymania się od przyjmowania regulacji, które owo prawo mogłyby pozbawiać ochrony prawnej lub też ochronę tę ograniczać" (zob. wyroki TK: z dnia 13 kwietnia 1999 r., sygn. akt K 36/98; z dnia 29 czerwca 2004 r., sygn. akt P 20/02; z dnia 21 grudnia 2005 r., sygn. akt SK 10/05; z dnia 20 kwietnia 2009 r., sygn. akt SK 55/08). Ochrona zapewniana własności i innym majątkowym prawom podmiotowym, zgodnie $\mathrm{z}$ art. 64 ust. 1 oraz art. 21 ust. 1 Konstytucji, musi być realna. Jako kryterium weryfikacji tej cechy służy skuteczność realizacji określonego prawa podmiotowego w konkretnym otoczeniu systemowym, w którym ono funkcjonuje (zob. orzeczenia powołane powyżej oraz wyroki TK: z dnia 25 lutego 1999 r., sygn. akt K 23/98; z dnia 12 stycznia 2000 r., sygn. akt 
P 11/98; z dnia 19 grudnia 2002 r., sygn. akt K 33/02; z dnia 20 stycznia 2004 r., sygn. akt SK 26/03). Trybunał Konstytucyjny podkreślał jednocześnie wielokrotnie, że do kluczowych aspektów prawa własności oraz innych zbywalnych praw majątkowych należy możliwość rozporządzania nimi (por. wyroki TK: z dnia 2 października 2002 r., sygn. akt K 48/01; z dnia 16 października 2007 r., sygn. akt K 28/06; z dnia 17 grudnia 2008 r., sygn. akt P 16/08; z dnia 15 lipca 2009 r., sygn. akt K 64/09; z dnia 1 lipca 2014 r., sygn. akt SK 6/12). Nie ulega wątpliwości, że uprawnienia akcjonariusza są zbywalne i że możliwość zbycia lub obciążenia akcji należy do najważniejszych instrumentów czerpania korzyści z inwestycji w te papiery wartościowe.

Trybunał Konstytucyjny podkreśla, że ochrona własności i innych praw majątkowych nie ma charakteru absolutnego, a jej ograniczenia są dopuszczalne $\mathrm{z}$ zachowaniem warunków przewidzianych w art. 31 ust. 3 oraz art. 64 ust. 2 i ust. 3 Konstytucji, tj. na podstawie ustawy i z poszanowaniem zasad równości oraz proporcjonalności (por. np. wyroki TK: z dnia 3 października 2000 r., sygn. akt K. 33/99; z dnia 14 lipca 2003 r., sygn. akt SK 42/01; z dnia 12 maja 2004 r., sygn. akt SK 43/02; z dnia 15 maja 2006 r., sygn. akt P 32/05; z dnia 16 października 2007 r., sygn. akt K 28/06; z dnia 8 grudnia 2011 r., sygn. akt P 331/10; z dnia 15 maja 2019 r., sygn. akt SK 31/17).

Zasadę proporcjonalności można wywieść z art. 31 ust. 3 Konstytucji (W. Sokolewicz, M. Zubik, op. cit., s. 153). Jednocześnie istnieje szereg rozstrzygnięć TK uznających, że zasadę tę można wywieść z art. 2 Konstytucji jako samodzielnej podstawy prawnej (por. np. wyroki TK: z dnia 18 lutego 2003 r., sygn. akt K 24/02; z dnia 15 listopada 2005 r., sygn. akt P 3/05; z dnia 12 stycznia 1999 r., sygn. akt P 2/98; z dnia 29 stycznia 2002 r., sygn. akt K 19/01) lub w związku z art. 31 ust. 3 (por. np. wyrok TK z dnia 25 października 2004 r., sygn. akt SK 33/03). W innych rozstrzygnięciach TK jako podstawę zasady proporcjonalności wskazuje art. 31 ust. 3 Konstytucji (por. np. wyrok TK z dnia 17 stycznia 2019 r., sygn. akt $\mathrm{K} 1 / 18$, oraz cytowane tam orzecznictwo). W literaturze wskazuje się niekiedy, że jedną z przesłanek dopuszczalności ograniczania w drodze ustawy wolności i praw konstytucyjnych wynikających z art. 31 ust. 3 Konstytucji jest konieczność zrównoważenia wprowadzonych ograniczeń z oczekiwanymi korzyściami w ochronie wartości, ze względu na które ograniczenia zostały wprowadzone. Artykuł 2 Konstytucji ma natomiast wyrażać szerzej rozumianą zasadę proporcjonalności działania władz publicznych, przejawiającą się m.in. w zakazie arbitralnego traktowania jednostek oraz ogólniejszym zakazie nadmiernej ingerencji państwa w stosunki społeczne (W. Sokolewicz, M. Zubik, op. cit., s. 153-154; P. Tuleja, op. cit., nb. 46). Wobec zróżnicowania stanowiska TK dotyczącego konstytucyjnej podstawy prawnej, z której wywodzona jest ta zasada, Sejm pozostaje przy kwalifikacji dokonanej przez skarżących, którzy wywodzą ją z art. 2 Konstytucji. Jednocześnie Sejm zauważa, że analiza dopuszczalności ograniczenia konstytucyjnych praw majątkowych, o których mowa w art. 64 ust. 1 Konstytucji, 
już sama w sobie wymaga przeprowadzenia testu proporcjonalności jako jednej z przesłanek wynikających z art. 31 ust. 3 Konstytucji.

\section{- 3. Ocena zgodności}

1. W pierwszej kolejności Sejm pragnie zwrócić uwagę, że zarzuty skarżących opierają się m.in. na założeniach faktycznych, które nie mogą być uznane za całkowicie poprawne. Skarżący twierdzą mianowicie, że działanie sprawcy przestępstwa opisanego w zaskarżonym przepisie, polegające na składaniu zleceń lub dokonywaniu transakcji, które wprowadzają w błąd lub mogą wprowadzić w błąd co do popytu, ale nie mogą wprowadzić w błąd co do ceny, nie są społecznie szkodliwe i nie naruszają interesów innych podmiotów. W rzeczywistości wprowadzenie w błąd co do wielkości rzeczywistego popytu lub podaży jest działaniem naruszającym zarówno zbiorowe, jak i indywidualne interesy na rynku instrumentów finansowych. Ryzyko ponoszone przez inwestora na rynku wynika bowiem nie tylko z możliwości wahań ceny, ale także z płynności aktywów stanowiących przedmiot inwestycji. Przez płynność rozumie się zdolność do sprzedaży lub kupna aktywów znacznej wartości bez wpływania na cenę rynkową (por. np. J. Downes, J.E. Goodman, Dictionary of Finance and Investment Terms, Hauppaugue NY 2003, s. 386). W przypadku aktywów o niskiej płynności znalezienie nabywcy na sprzedawane aktywa wiąże się z koniecznością zaoferowania znacznego rabatu w stosunku do bieżącej ceny rynkowej, a w krańcowym przypadku może być w ogóle niemożliwe. Odpowiednio w odniesieniu do nabywcy w przypadku aktywów o niskiej płynności nabywanie istotnej liczby tych aktywów doprowadzi do znacznej zwyżki ceny. Niska płynność aktywów zwiększa w związku z tym ryzyko poniesienia strat, ponieważ prowadzi do istotnego wzrostu cen przy ich nabywaniu oraz istotnego spadku przy ich sprzedaży. Istnieje relacja między płynnością aktywów danego rodzaju a przeciętną wielkością popytu i podaży na te aktywa oraz przeciętnym poziomem obrotu tymi aktywami. Jest to relacja złożona. Można jednak w pewnym uproszczeniu poprawnie twierdzić, że istnieje pozytywna korelacja między płynnością aktywów a wielkością popytu i podaży oraz przeciętnym wolumenem obrotu (por. np. D. Lam, B.-X. Lin, D. Michayl, Demand and Supply and Their Relationship to Liquidity: Evidence from the SerP 500 Change to Free Float, „Financial Analysts Journal” 2011, vol. 67, no. 1, s. 70; A. Sarr, T. Lybek, Measuring Liquidity in Financial Markets, „IMF Working Paper” 2012, December, s. 11-14). Wartość oraz wolumen obrotów są w związku $\mathrm{z}$ tym informacjami istotnymi w kontekście oceny ryzyka ponoszonego przez inwestora. Są to także informacje istotne z punktu widzenia wierzycieli przyjmujących instrumenty finansowe jako zabezpieczenie. Aktywa o mniejszej płynności niosą ze sobą większe ryzyko prawidłowej wyceny zabezpieczenia, a także większe ryzyko poniesienia straty w razie realizacji zabezpieczenia ze względu na większe prawdopodobieństwo wpływu realizacji zabezpieczenia na spadek ceny przedmiotu zabezpieczenia. Informacja o wysokości popytu i podaży jest także 
istotnym elementem przy podejmowaniu decyzji inwestycyjnych w oparciu o tzw. analizę techniczną, czyli prognozowanie kursu akcji na podstawie historycznych danych o rynku oraz statystyk. Wartość i wolumen obrotów, a także dane dotyczące zmienności tych wartości są traktowane jako ważne wskaźniki zapowiadające zmianę trendów na rynku instrumentów finansowych (por. np. R.W. Schabacker, Technical Analysis and Stock Market Profits, Petersfield 2005, s. 293 i n.). Zdaniem Sejmu ocena poziomu efektywności tego sposobu analizy nie ma znaczenia dla oceny szkodliwości społecznej transakcji wprowadzających w błąd co do poziomu obrotów. Stosowanie tego sposobu analizy przez inwestorów jest faktem, a działania wpływające w sposób sztuczny na ocenę poziomu popytu i podaży na instrumenty finansowe wpływają lub mogą wpłynąć na decyzje inwestycyjne inwestorów. Sejm zauważa także, że wielkość popytu i podaży na określone walory ma także wpływ na handel algorytmiczny na rynku instrumentów finansowych. Handel ten polega na zautomatyzowanym podejmowaniu decyzji inwestycyjnych przy wykorzystaniu infrastruktury informatycznej. Zlecenie zbycia lub nabycia instrumentu finansowego przekazywane jest wtedy bez wiedzy inwestora w wyniku zastosowania założonych z góry algorytmów, uwzględniających na bieżąco zmieniające się dane rynkowe (por. np. A.Ch. Lange, The noisy motions of instruments: The performative space of high-frequency trading [w:] Performing the Digital, red. M. Leeker, I. Schipper, T. Beyes, Bielefeld 2017, s. 101 i n.; Technical Committee of the International Organization of Securities Commissions, Regulatory Issues Raised by the Impact of Technological Changes on Market Integrity and Efficiency, 10.07.2011, https://www.iosco.org/library/pubdocs/pdf/IOSCOPD354. pdf [dostęp 17 listopada 2019 r.]). Dokonywanie czynności, których jedynym lub przeważającym celem ma być kreowanie poziomu obrotu, wpływa lub może wpływać na zastosowanie tych algorytmów w sposób sztuczny, kreując decyzje inwestycyjne. $Z$ przedstawionych rozważań wynika, że dokonywanie transakcji w celu zawyżenia statystyki obrotów danym walorem giełdowym jest działaniem, które narusza zarówno abstrakcyjne dobro prawne, jakim jest ład informacyjny na rynku instrumentów finansowych, jak i konkretne interesy szeregu podmiotów działających jako inwestorzy na rynku instrumentów finansowych oraz wierzyciele, przyjmujący zabezpieczenia. Działania mające charakter manipulacji transakcyjnej, które mogą wywołać błędną ocenę dotyczącą wielkości popytu lub podaży, należy zakwalifikować jako czyn szkodliwy społecznie nawet w sytuacji, w której nie może on prowadzić do ustalenia sztucznego poziomu ceny ani wywołać błędnego przekonania o realnej wycenie danego waloru.

2. W sposób szczególny za działania szkodliwe społecznie należy uznać działania mające wpłynąć w sposób sztuczny na skład głównych indeksów giełdowych. Zakwalifikowanie akcji danej spółki do głównego indeksu giełdy wiąże się z szeregiem konsekwencji prawnych. Zgodnie z art. 12 rozporządzenia delegowanego Komisji (UE) 2015/61 z dnia 10 października 2014 r. uzupełniającego rozporządzenie Parlamentu Europejskiego i Rady (UE) 575/2013 w odniesieniu 
do wymogu pokrycia wypływów netto dla instytucji kredytowych (Dz. Urz. UE L 11 z 17.01.2015, s. 1) akcje jako przedmiot inwestycji instytucji kredytowej mogą być zakwalifikowane do aktywów płynnych (poziomu 2B), jeżeli wchodzą w skład głównego indeksu. Akcje nienależące do głównego indeksu traktowane są $\mathrm{w}$ związku z tym także z przyczyn formalnych jako mniej płynne i dla instytucji kredytowych są już również z przyczyn formalnych znacznie mniej atrakcyjnym przedmiotem inwestycji niż akcje należące do głównego indeksu. Analogiczna okoliczność dotyczy przyjmowania akcji jako przedmiotu zabezpieczenia wierzytelności instytucji kredytowych. Zgodnie z art. 197 ust. 1 lit. f rozporządzenia Parlamentu Europejskiego i Rady (UE) 575/2013 z dnia 26 czerwca 2013 r. w sprawie wymogów ostrożnościowych dla instytucji kredytowych i firm inwestycyjnych zmieniającego rozporządzenie (UE) 648/2012 (Dz. Urz. UE L 176 z 27.06.2013, s. 1) instytucje kredytowe mogą uwzględniać zabezpieczenia na akcjach jako narzędzia ograniczania ryzyka kredytowego pod warunkiem, że akcje te wchodzą w skład głównego indeksu giełdowego. Zgodnie z tabelą I załącznika I rozporządzenia wykonawczego Komisji (UE) 2016/1646 z dnia 13 września 2016 r. ustanawiającego wykonawcze standardy techniczne w odniesieniu do indeksów głównych i uznanych giełd zgodnie z rozporządzeniem Parlamentu Europejskiego i Rady (UE) nr 575/2013 w sprawie wymogów ostrożnościowych dla instytucji kredytowych i firm inwestycyjnych (Dz. Urz. UE L 245 z 14.09.2016, s. 5) do głównych indeksów w rozumieniu przepisów o adekwatności kapitałowej instytucji kredytowych należy indeks WIG20. W pierwszym motywie tego rozporządzenia Komisja wskazuje, że główne indeksy akcji powinny składać się przede wszystkim $\mathrm{z}$ akcji, w których przypadku można racjonalnie spodziewać się ich zbycia w sytuacji, gdy instytucja ma potrzebę ich upłynnienia. Wynika stąd niedwuznacznie, że dla prawidłowego ustalenia składu głównego indeksu najważniejszym czynnikiem jest płynność walorów należących do indeksu. Z tego względu kryteriami bazowymi w ustaleniu składu indeksu WIG20 są m.in. liczba akcji w wolnym obrocie większa od $10 \%$, wartość akcji w wolnym obrocie większa od $1 \mathrm{mln}$ euro oraz pozostawanie poza strefą niskiej płynności (zob. WIG20 - metodologia indeksu akcji Głównego Rynku GPW, https://www. gpw.pl/pub/GPW/files/PDF/indeksy/zmiana2/2018_12_30_WIG20.pdf [dostęp 17 listopada 2019 r.]). Z tego powodu składanie zleceń, których celem jest wyłącznie kreacja wielkości wolnego obrotu, wprowadza lub może wprowadzać w błąd co do istotnych cech instrumentu finansowego wchodzącego w skład głównego indeksu. Jest to działanie, które narusza interesy inwestorów, wierzycieli, przyjmujących akcje jako zabezpieczenie, oraz obniża przejrzystość rynku jako zorganizowanej instytucji wymiany. Nie można zgodzić się z twierdzeniem skarżących, że działanie polegające na sztucznym generowaniu obrotu w celu utrzymania korzyści wynikających z przynależności danej spółki do głównego indeksu nie odbywa się kosztem innych inwestorów. Liczba spółek wchodzących w skład indeksu WIG20 jest ograniczona. Utrzymanie akcji spółki w głównym 
indeksie giełdy w wyniku manipulacji pozbawia korzyści akcjonariuszy spółki, która powinna znaleźć się w składzie indeksu, gdyby nie doszło do manipulacji.

3. Za nietrafne należy także uznać zarzuty skarżących dotyczące faktu penalizacji transakcji, które zostały przeprowadzone zgodnie z zasadami obrotu na rynku giełdowym. Szczegółowe zasady obrotu giełdowego określają w szczególności sposób zawierania transakcji oraz inne procedury dotyczące obrotu giełdowego. Dotyczy to także zasad zawierania transakcji „cross”. Zawarcie umowy zgodnie z procedurą nie przesądza jednak o legalności zachowania sprawcy. Zasady obrotu giełdowego określają narzędzia, którymi inwestorzy i zastępujące ich firmy inwestycyjne posługują się we wtórnym obrocie instrumentami finansowymi. W żadnym przypadku zachowanie proceduralnej poprawności transakcji nie decyduje o tym, czy dana transakcja nie jest szkodliwa dla ładu informacyjnego na rynku instrumentów finansowych oraz czy może ona wprowadzić w błąd konkretnych inwestorów na rynku. Sformułowane wyżej spostrzeżenia dotyczące szkodliwości transakcji mogących wprowadzić w błąd co do wielkości popytu lub podaży bez wprowadzania w błąd co do ceny instrumentów finansowych pozostają aktualne niezależnie od tego, czy manipulacja została dokonana w zgodzie z procedurami zawierania transakcji na rynku.

4. W kontekście poczynionych wyżej ustaleń należy przyjąć, że penalizacja dokonywania transakcji wprowadzających lub mogących wprowadzić w błąd co do wielkości popytu lub podaży na rynku instrumentów finansowych jest ograniczeniem prawa własności, które znajduje usprawiedliwienie w kryteriach wynikających z art. 31 ust. 3 Konstytucji.

Po pierwsze, penalizacja manipulacji transakcyjnej wprowadzającej w błąd co do popytu lub podaży na rynku instrumentów finansowych wynika z ustawy. Po drugie, manipulacja taka godzi w ład informacyjny na rynku instrumentów finansowych, który należy zakwalifikować jako element porządku publicznego. Manipulacja taka godzi także w indywidualne interesy majątkowe osób nabywających instrumenty finansowe jako przedmiot inwestycji lub zabezpieczenia. W przypadku manipulacji dotyczącej struktury głównego indeksu giełdy narusza ona także interesy i prawa inwestorów, których akcje weszłyby w skład indeksu, gdyby nie doszło do manipulacji. Ograniczenie możliwości rozporządzania instrumentami finansowymi wynikające z penalizacji manipulacji służy zatem ochronie wartości uznanych na gruncie art. 31 ust. 3 Konstytucji. Posłużenie się przez ustawodawcę karnoprawnym narzędziem ochrony należy uznać za rozwiązanie konieczne do ochrony tych wartości. Ograniczenie narzędzi ochrony do sankcji prywatnoprawnych byłoby niewystarczające. Z jednej strony, narzędzia takie są odpowiednie do ochrony indywidualnych interesów inwestorów. Nie są w stanie chronić natomiast abstrakcyjnego dobra prawnego, jakim jest ład informacyjny na rynku instrumentów finansowych. Z drugiej strony, prawidłowe funkcjonowanie rynku instrumentów finansowych wymaga zaufania inwestorów. Instrumenty ochrony rynku powinny zatem działać już na przedpolu bezpośred- 
nich naruszeń. Stąd penalizacją objęte zostało już samo narażenie interesów publicznych i prywatnych w postaci podejmowania działań, które mogą wprowadzać w błąd. Instrumenty prawa prywatnego takie jak roszczenia odszkodowawcze mogą zostać zastosowane dopiero ex post (po powstaniu naruszenia). Ich efektywność jest także ograniczona ze względu na trudności dowodowe dotyczące m.in. związku przyczynowego między manipulacją a konkretną szkodą inwestora. Nie mniej kłopotliwa może okazać się np. wycena korzyści utraconych przez inwestorów, których akcje w wyniku manipulacji nie weszły do głównego indeksu. Uzasadnia to konieczność zastosowania sankcji karnych jako efektywnego narzędzia ochrony porządku publicznego oraz indywidualnych interesów inwestorów. Po trzecie, Sejm zauważa, że ingerencja w prawo rozporządzenia instrumentami finansowymi wynikająca z penalizacji manipulacji transakcyjnej w zakresie wskazanym w skargach nie narusza istoty praw majątkowych uprawnionych $\mathrm{z}$ akcji i innych instrumentów finansowych. Do istoty tych uprawnień należy możliwość wykonywania praw z tych instrumentów oraz rozporządzania nimi. Zakaz manipulacji nie wyklucza żadnej z tych możliwości. Jego zakres jest stosunkowo wąski. Można przyjąć, że w sposób oczywisty zakaz manipulacji nie wyklucza możliwości czerpania korzyści z inwestycji w instrumenty finansowe. Tę możliwość należy zakwalifikować jako istotę praw nabywców instrumentów finansowych. Pozostawienie takiej możliwości przesądza o spełnieniu przez zaskarżony przepis wynikających z art. 31 ust. 3 Konstytucji przesłanek ograniczenia w zakresie korzystania z konstytucyjnych wolności i praw.

5. W związku z powyższym Sejm wnosi o stwierdzenie, że art. 183 ust. 1 u.o.i.f. w pierwotnym brzmieniu obowiązującym przed 6 maja 2017 r. w związku z art. 39 ust. 2 pkt 1 u.o.i.f., uchylonym nowelizacją z 2017 r., w zakresie, w jakim pozwala uznać za czyn zabroniony pod groźbą kary składanie zleceń lub zawieranie transakcji zgodnych ze szczególnymi regulacjami ustalonymi dla obrotu giełdowego przez spółkę prowadzącą rynek regulowany dokonywanych między akcjonariuszami notowanej na giełdzie spółki, które to zlecenia lub transakcje wpływają na wielkość obrotu akcjami spółki i mogą wpływać na pozycję spółki w publikowanych przez spółkę prowadzącą rynek regulowany indeksach, lecz nie wprowadzają lub nie mogą wprowadzać innych inwestorów w błąd co do ceny akcji, jest zgodny z art. 64 ust. 1 w związku z art. 2 Konstytucji.

\section{Zarzut naruszenia art. 47 Konstytucji}

\section{- 1. Zarzuty skarżących}

Skarżący podkreślają, że opisanie ich zachowania jako manipulacji łączy się ze zdecydowanie negatywną oceną społeczną. Zarówno w języku potocznym, jak i w specjalistycznym języku używanym przez inwestorów giełdowych i innych uczestników życia gospodarczego jest to określenie, które stygmatyzuje, odbiera wiarygodność podmiotowi, którego działania zostały uznane za manipula- 
cję. Nazwanie w ustawie manipulacją działań, które nie są, zdaniem skarżących, szkodliwe społecznie, ponieważ nie wpływają na cenę akcji, a także nie wprowadzają w błąd innych inwestorów giełdowych i nie są dokonywane z zamiarem uzyskania korzyści majątkowych kosztem innych inwestorów giełdowych, narusza cześć i dobre imię inwestorów. Tym samym, w opinii skarżących, zaskarżany przepis pozostaje w sprzeczności z wynikającym $\mathrm{z}$ art. 47 Konstytucji prawem do ochrony czci i dobrego imienia.

\section{- 2. Wzorzec konstytucyjny}

1. Zgodnie $z$ art. 47 Konstytucji każdy ma prawo do ochrony prawnej życia prywatnego, rodzinnego, czci i dobrego imienia oraz do decydowania o swoim życiu osobistym. W ten sposób uregulowane zostały dwie odrębne sytuacje: po pierwsze, prawo jednostki do prawnej ochrony wskazanych w pierwszej części przepisu sfer jej życia; po drugie, wolność decydowania w sprawach określonych w końcowej jego części. Pierwszemu prawu jednostki towarzyszyć musi ustawowa regulacja pozwalająca bronić prywatności, życia rodzinnego, czci i dobrego imienia. Natomiast drugie oznacza zakaz ingerencji w wolność kształtowania przez jednostkę jej życia osobistego. Zdaniem Trybunału Konstytucyjnego wolność ta jest również jeszcze jednym z przejawów ogólnej wolności człowieka (art. 31 ust. 1) oraz wolności osobistej sensu stricto, zagwarantowanej przez art. 41 ust. 1 Konstytucji. Obie normy konstytucyjne zawarte w art. 47 Konstytucji określa się jako prawo do prywatności (por. np. wyroki TK: z dnia 2 kwietnia 2001 r., sygn. akt SK 10/09; z dnia 9 lipca 2009 r., sygn. akt SK 48/05; z dnia 5 marca 2013 r., sygn. akt U 2/11; z dnia 19 czerwca 2018 r., sygn. akt SK 19/17). Należy także mieć na uwadze, że poszanowanie prywatności jest ściśle powiązane z konstytucyjnym nakazem ochrony godności ludzkiej (art. 30 Konstytucji - por. np. wyrok TK z dnia 16 maja 2018 r., sygn. akt SK 18/17).

2. Prawo do ochrony czci i dobrego imienia jest elementem normy wynikającej z art. 47 Konstytucji. Tworzy ono domniemanie poprawnego zachowania się jednostki w sferze życia prywatnego oraz publicznego zarówno aktualnie, jak i w przeszłości (tak P. Sarnecki, komentarz do art. 47 [w:] Konstytucja Rzeczypospolitej Polskiej. Komentarz, t. I, red. L. Garlicki, M. Zubik, Warszawa 2016, s. 4; M. Wild, komentarz do art. 47 [w:] Konstytucja Rzeczypospolitej Polskiej. Komentarz, t. I, red. M. Safjan, L. Bosek, Warszawa 2016, nb. 78). Przez naruszenie czci i dobrego imienia należy rozumieć w szczególności przypisanie osobie cech lub właściwości, które mogą ją poniżyć w opinii publicznej lub narazić na utratę zaufania potrzebnego na danym stanowisku, w danym zawodzie lub przy danym rodzaju działalności (zob. wyroki SN: z dnia 29 października 1971 r., sygn. akt II CR 455/71; z dnia 13 czerwca 1980 r., sygn. akt IV CR 182/90; z dnia 3 września 2009 r., sygn. akt I CSK 44/09). Ocena okoliczności, czy doszło do poniżenia lub narażenia na utratę zaufania potrzebnego $\mathrm{w}$ danym środowisku, decyduje reakcja przeciętnego odbiorcy, tj. reakcja, jaką wywołuje w społeczeństwie lub 
odpowiednio w określonej grupie zawodowej zdarzenie stanowiące podstawę żądania ochrony (zob. wyroki SN: z dnia 17 czerwca 2004 r., sygn. akt V CK 69/04; z dnia 19 maja 2004 r., sygn. akt I CK 636/03; z dnia 26 października 2001 r., sygn. akt V CKN 195/01). Prawo do ochrony czci i dobrego imienia rozważa się najczęściej w kontekście granic wolności wypowiedzi (por. np. M. Wild, op. cit., nb. 78). Naruszenie prawa do ochrony czci lub dobrego imienia może być jednak także następstwem zachowania podmiotów publicznych, którym konstytucyjne prawo swobody wypowiedzi nie przysługuje (por. np. orzeczenie TK z dnia 19 czerwca 1992 r., sygn. akt U 6/92). W literaturze i orzecznictwie TK zwraca się jednocześnie uwagę, że naruszenie prawa do czci i dobrego imienia ma charakter konkretny. Samo ustanowienie abstrakcyjnych norm, które wprowadzają sankcje za określone zachowania, nie jest jeszcze równoznaczne z naruszeniem czci i dobrego imienia osób, które się takich zachowań dopuściły. W wyroku z dnia 14 lipca 2003 r. (sygn. akt SK 42/01) Trybunał Konstytucyjny stwierdził, że „same przepisy prowadzące do utraty sędziowskiego stanu spoczynku [...] nie odbierają nikomu same przez się jego czci czy dobrego imienia. Faktyczna utrata czci i dobrego imienia, albo poczucie takiej utraty, wiąże się więc $z$ indywidualną oceną zachowań konkretnych osób z przeszłości, nie zaś z literą obecnego prawa”. Z przytoczonego wyroku wynika także, że akt normatywny ustanawiający sankcje związane z określonym zachowaniem nie narusza art. 47 Konstytucji, jeżeli to zachowanie godzi w społecznie akceptowane wartości. Prawo do ochrony czci i dobrego imienia należy do podstawowych i niezbywalnych praw jednostki. $Z$ tego względu, zdaniem Sejmu, art. 47 Konstytucji należy uznać za adekwatny wzorzec kontroli we wszystkich przypadkach, w których zastosowanie inkryminowanego przepisu może prowadzić do ingerencji w to prawo, nawet wtedy, gdy problem ochrony czci i dobrego imienia ma charakter pochodny w stosunku do innych problemów konstytucyjnych, takich jak w niniejszym postępowaniu zagadnienie dopuszczalności penalizacji określonego zachowania.

3. Prawo do prywatności nie ma charakteru absolutnego i jako takie może być limitowane. Wszelkie ograniczenia tego prawa powinny być oceniane przez pryzmat art. 31 ust. 3 Konstytucji (zob. np. P. Sarnecki, op. cit., s. 4; wyroki TK: z dnia 21 października 1998 r., sygn. akt K 24/98; z dnia 11 kwietnia 2000 r., sygn. akt K 15/98; z dnia 20 listopada 2002 r., sygn. akt K 41/02; z dnia 20 marca 2006 r., sygn. akt K 17/05), który formułuje kumulatywnie ujęte przesłanki dopuszczalności ograniczeń w korzystaniu z konstytucyjnych praw i wolności. Są to: 1) ustawowa forma ograniczenia; 2) istnienie w państwie demokratycznym konieczności wprowadzenia ograniczenia; 3) funkcjonalny związek ograniczenia $\mathrm{z}$ realizacją wskazanych $\mathrm{w}$ art. 31 ust. 3 Konstytucji wartości (bezpieczeństwo państwa, porządek publiczny, ochrona środowiska, zdrowia i moralności publicznej, wolności i praw innych osób); 4) zakaz naruszania istoty danego prawa lub wolności (zob. np. wyrok TK z dnia 30 maja 2007 r., sygn. akt SK 68/06; por. również: L. Garlicki, komentarz do art. 31 [w:] Konstytucja Rzeczypospolitej Polskiej. Komentarz, t. III, 
red. L. Garlicki, Warszawa 2003, s. 14 i n.; J. Zakolska, Zasada proporcjonalności w orzecznictwie Trybunału Konstytucyjnego, Warszawa 2008, s. 115-141).

\section{- 3. Analiza zgodności}

1. Ocenę zgodności zaskarżonego przepisu z art. 47 Konstytucji można potraktować jako krótkie podsumowanie przedstawionych wyżej rozważań. W kontekście reguły sformułowanej przez Trybunał Konstytucyjny w wyroku z dnia 14 lipca 2003 r. (sygn. akt SK 42/01) należy stwierdzić, że samo wydanie zaskarżonych przepisów nie naruszyło w jakikolwiek sposób prawa do ochrony czci i dobrego imienia skarżących. Negatywna ocena manipulacji na rynku instrumentów finansowych, w tym manipulacji, której istotą jest wprowadzenie w błąd lub zagrożenie wprowadzeniem w błąd wyłącznie co do popytu lub podaży na instrumenty finansowe, wynika z obiektywnej społecznej szkodliwości takiego zachowania. Istota tej szkodliwości została wyjaśniona powyżej. W kontekście zarzutów dotyczących sprzeczności zaskarżonego przepisu z art. 47 Konstytucji należy wskazać jedynie, że negatywna ocena czynów opisanych w zaskarżonym przepisie znajduje uzasadnienie zarówno na płaszczyźnie społecznej, jak i etycznej oraz ekonomicznej. Nie można zatem podzielić zarzutów skarżących co do niezgodności zaskarżonego przepisu z powołanym przez nich wzorcem konstytucyjnym.

2. Wobec powyższego Sejm wnosi o stwierdzenie, że art. 183 ust. 1 u.o.i.f. w pierwotnym brzmieniu obowiązującym przed 6 maja 2017 r. w związku z art. 39 ust. 2 pkt 1 u.o.i.f., uchylonym nowelizacją z 2017 r., w zakresie, w jakim pozwala uznać za czyn zabroniony pod groźbą kary składanie zleceń lub zawieranie transakcji zgodnych ze szczególnymi regulacjami ustalonymi dla obrotu giełdowego przez spółkę prowadzącą rynek regulowany dokonywanych między akcjonariuszami notowanej na giełdzie spółki, które to zlecenia lub transakcje wpływają na wielkość obrotu akcjami spółki i mogą wpływać na pozycję spółki w publikowanych przez spółkę prowadzącą rynek regulowany indeksach, lecz nie wprowadzają lub nie mogą wprowadzać innych inwestorów w błąd co do ceny akcji, jest zgodny z art. 47 Konstytucji.

\section{Bibliografia}

Banaszak B., Konstytucja Rzeczypospolitej Polskiej. Komentarz, Warszawa 2012, komentarz do art. 42.

Błachnio-Parzych A., komentarz do art. 39 u.o.i.f. [w:] Prawo rynku kapitałowego, red. M. Wierzbowski, Warszawa 2014.

Bogdan G., komentarz do art. 173 k.k. [w:] Kodeks karny. Komentarz, red. W. Wróbel, A. Zoll, Warszawa 2017.

Bojarski J., Kalinowski M., Składanie zleceń lub dokonywanie transakcji na rynku $w$ celu dokonania optymalizacji podatkowej a manipulacja karalna na podstawie 
art. 183 ust. 1 ustawy o obrocie instrumentami finansowymi, „Studia Iuridica Toruniensia” 2016, t. XVIII, nr 1.

Cieślak M., Polskie prawo karne. Zarys systemowego ujęcia, Warszawa 1994.

Czeszejko-Sochacki Z., Formy naruszenia konstytucyjnych wolności lub praw [w:] Skarga konstytucyjna, red. J. Trzciński, Warszawa 2000.

Dębski R., Pozaustawowe znamiona przestępstwa. O ustawowym charakterze norm prawa karnego i znamionach typu czynu zabronionego nie określonych w ustawie, Łódź 1995.

Downes J., Goodman J.E., Dictionary of Finance and Investment Terms, Hauppaugue NY 2003.

Gardocki L., Prawo karne, Warszawa 2007.

Gardocki L., Prawo karne, Warszawa 2009.

Garlicki L., komentarz do art. 31 [w:] Konstytucja Rzeczypospolitej Polskiej. Komentarz, t. III, red. L. Garlicki, Warszawa 2003.

Hermalin B.E., Katz A.W., Craswell R. [w:] Handbook of Law and Economics, t. I, red. A.M. Polinsky, S. Shavell, Amsterdam 2007, https://doi.org/10.1016/S15740730(07)01001-8.

Hryniewicz E., Przestępstwa abstrakcyjnego i konkretnego zagrożenia dóbr prawnych, Warszawa 2012.

Jamróz L., Skarga konstytucyjna. Wstępne rozpoznanie, Białystok 2011.

Korn K., Pojęcie manipulacji instrumentami finansowymi, cz. 2, „Transformacje Prawa Prywatnego" 2012, z. 4.

Kunicka-Michalska B., komentarz do art. 4 [w:] Kodeks karny. Komentarz, red. R.A. Stefański, Warszawa 2018.

Lachowski J., komentarz do art. 4 [w:] Kodeks karny. Komentarz, red. V. Konarska-Wrzosek, Warszawa 2018.

Lam D., Lin B.-X., Michayl D., Demand and Supply and Their Relationship to Liquidity: Evidence from the SeP 500 Change to Free Float, „Financial Analysts Journal” 2011, vol. 67, no. 1, https://doi.org/10.2469/faj.v67.n1.3.

Lange A.Ch., The noisy motions of instruments: The performative space of high-frequency trading [w:] Performing the Digital, red. M. Leeker, I. Schipper, T. Beyes, Bielefeld 2017, https://doi.org/10.14361/9783839433553-005.

Martysz C., Manipulacje instrumentami finansowymi i insider trading. Analiza prawno-ekonomiczna, Warszawa 2015.

Sarnecki P., komentarz do artykułu 47 Konstytucji [w:] Konstytucja Rzeczypospolitej Polskiej. Komentarz, t. I, red. L. Garlicki, M. Zubik, Warszawa 2016.

Sarr A., Lybek T., Measuring Liquidity in Financial Markets, „IMF Working Paper” 2012, December, https://doi.org/10.5089/9781451875577.001.

Schabacker R.W., Technical Analysis and Stock Market Profits, Petersfield 2005.

Schwark E., \$20a WpHG [w:] Kapitalmarktrechts-Kommentar, red. E. Schwark, D. Zimmer, Monachium 2010.

Sokolewicz W., Zubik M., komentarz do art. 2 Konstytucji [w:] Konstytucja Rzeczypospolitej Polskiej. Komentarz, t. I, red. L. Garlicki, M. Zubik, Warszawa 2016. 
Sołtys A., Obowiązek wykładni zgodnej w orzecznictwie Trybunału Konstytucyjnego, cz. 1, „Europejski Przegląd Sądowy” 2014, nr 4.

Sójka T., komentarz do art. 39 u.o.i.f. [w:] Prawo rynku kapitałowego. Komentarz, red. T. Sójka, Warszawa 2015.

Spyra M. [w:] System prawa handlowego, t. IV, red. M. Stec, Warszawa 2016.

Stelmach J., Brożek B., Załuski W., Dziesięć wykładów o ekonomii prawa, Warszawa 2007.

Technical Committee of the International Organization of Securities Commissions, Regulatory Issues Raised by the Impact of Technological Changes on Market Integrity and Efficiency, 10.07.2011, https://www.iosco.org/library/pubdocs/pdf/IOSCOPD354.pdf [dostęp 17 listopada 2019 r.].

Trzciński J., Wiącek M., komentarz do art. 79 Konstytucji [w:] Konstytucja Rzeczypospolitej Polskiej. Komentarz, t. I, red. L. Garlicki, M. Zubik, Warszawa 2016.

Tuleja P., komentarz do art. 2 Konstytucji [w:] Konstytucja Rzeczypospolitej Polskiej. Komentarz, t. I, red. M. Safjan, L. Bosek, Warszawa 2016.

Vicenzi S., Gli abusi del mercato, Trento 2012.

Vogel J., $\$ 22 \mathrm{a}$ WpHg [w:] Wertpapierhandelsrecht. Kommentar, red. H.D. Assmann, U.H. Schneider, Köln 2012.

Walker G., Purves R., Financial Services Law, Oxford 2018, https://doi.org/10.1093/ law/9780198793809.001.0001.

Warylewski J., Zasady techniki prawodawczej. Komentarz do rozporządzenia, Warszawa 2003.

Wąsek A., Kodeks karny. Komentarz, t. I, Gdańsk 1999.

Wehowsky W., \$20a WpHG [w:] Strafrechtliche Nebengesetze, red. G. Erbs, M. Kohlhaas, München 2012.

WIG20 - metodologia indeksu akcji Głównego Rynku GPW, https://www.gpw.pl/pub/GPW/ files/PDF/indeksy/zmiana2/2018_12_30_WIG20.pdf [dostęp 17 listopada 2019 r.].

Wild M., komentarz do art. 47 Konstytucji [w:] Konstytucja Rzeczypospolitej Polskiej. Komentarz, t. I, red. M. Safjan, L. Bosek, Warszawa 2016.

Wojtyczek K., Zasada proporcjonalności jako granica prawa karania, „Czasopismo Prawa Karnego i Nauk Penalnych" 1999, z. 2.

Worms A., Verbot der Marktmanipulation [w:] Handbuch des Kapitalanlagerechts, red. H.D. Assman, R.A. Schütze, München 2015.

Wróbel W., Zmiana normatywna i zasady intertemporalne, Warszawa 2003.

Zakolska J., Zasada proporcjonalności w orzecznictwie Trybunału Konstytucyjnego, Warszawa 2008.

Zieliński M., Wyznaczniki reguł wykładni prawa, „Ruch Prawniczy, Ekonomiczny i Socjologiczny" 1998, z. 3-4.

Ziouvas D., Walter T., Das neue Börsenstrafrecht mit Blick auf das Europarecht - zur Reform des $\$ 88$ Börs G, „Wertpapiermitteilungen” 2002, Nr. 29.

Żółtek S., komentarz do art. 4 [w:] Kodeks karny. Czesść ogólna. Art. 1-116, red. M. Królikowski, R. Zawłocki, Warszawa 2017. 